\title{
Kriz Yönetim Süreci Değerlendirme Ölçekleri Geliştirilme Çalışması (Development of Crisis Management Process Assesment Scales)
}

\author{
Mustafa ASLAN iD a Derman KÜÇÜKALTAN ${ }^{\text {iD }}$ b Doğan UZUN iD c \\ a İstanbul Arel Üniversitesi İktisadi ve İdari Bilimler Fakakültesi, İstanbul, Türkiye. maslan@hotmail.com \\ b İzmir Kavram Meslek Yüksek Okulu, İzmir, Türkiye. dermank2005@yahoo.com \\ c İstanbul Arel Üniversitesi, İstanbul, Türkiye. uzundogan@gmail.com
}

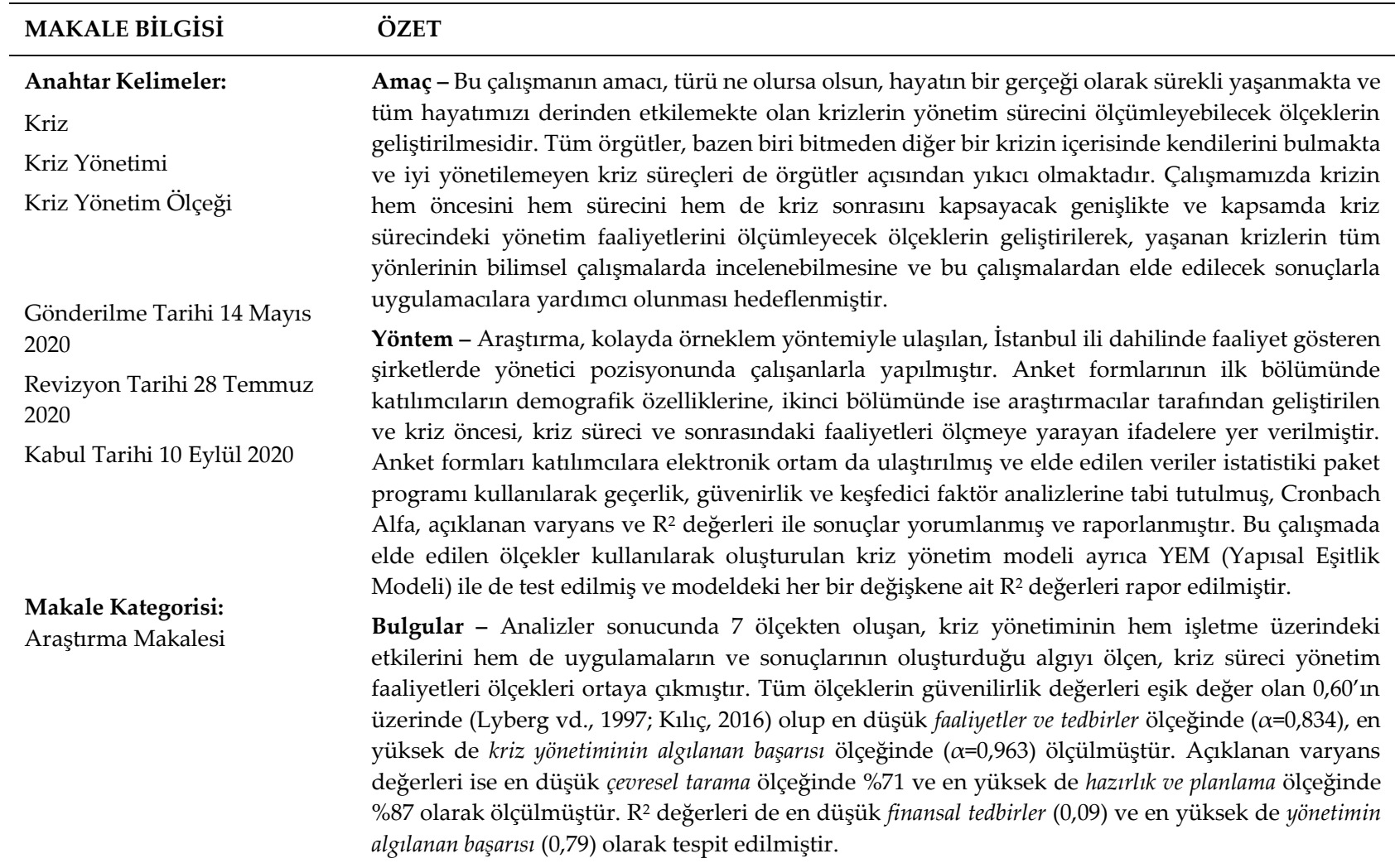

Tartışma - Toplamda elde edilen yedi ölçek ve bu ölçeklerle oluşturulan model dikkate alındığında, kriz zamanlarında en çok uygulanan finansal tedbirlerle tasarruf tedbirlerinin aslında krizin örgüt üzerindeki etkisini daha da kötüleştirdiği, üretim satış ve pazarlama faaliyetlerinin ise krizin kötü etkilerini elemine ettiği görülmektedir. Alınan finansal tedbirler aynı zamanda hem uygulamaların hem de yönetimin algılanan kriz yönetimindeki başarısını olumsuz yönde etkilediği, üretim satış ve pazarlamanın ise pozitif yönde etkilediği görülmektedir. Kriz öncesinde ve anında yapılan hazırlık faaliyetlerinin açıklanma oranı $\left(R^{2}=0,60\right)$ dikkate alındığında, çevresel taramanın bu safhaya en çok etkiyen faaliyet olduğu ortaya çıkmaktadır.

\begin{tabular}{ll}
\hline ARTICLE INFO & ABSTRACT \\
\hline Keywords: & $\begin{array}{l}\text { Purpose - The purpose of this study is to develop scales that can measure the management processes } \\
\text { of crises that are being experienced very often and affecting our entire life deeply. Almost all } \\
\text { organizations experience crises, and sometimes they find themselves in another crisis before the one } \\
\text { ends, and the crises that are not managed well become devastating for organizations. In our study, } \\
\text { it is aimed to develop scales that will measure the management activities of pre-crisis, during the } \\
\text { crisis Management } \\
\text { obtained post-crisis, and will be used in studies and to assist the practitioners with the results }\end{array}$ \\
& Crisis Management Scale
\end{tabular}

Design/methodology/approach - The research was carried out with executives working for companies operating in Istanbul, and the convenience sampling method used. The questionary form 
Received 14 May 2020

Revised 28 July 2020

Accepted 10 September 2020

Article Classification:

Research Article has two sections: the first section is to measure the demographic features of participants, while the second part consists of the statements developed by the researchers to measure the management activities before, during, and after the crisis experienced. The questionnaire forms were delivered to the participants in electronic form, and the data obtained were subjected to validity, reliability, and exploratory factor analysis using statistical package software. Test results and obtained Cronbach Alfa, percentage of the variance extracted, and $\mathrm{R}^{2}$ values were interpreted and reported. The crisis management model created using the scales obtained in this study was also tested with SEM (Structural Equation Model), and R2 values of each variable in the model were reported.

Findings - As a result of the analyzes, seven scales obtained to measure management activities and the perception created by these activities and their results. The reliability of all scales was above the threshold value of 0.60 (Lyberg et al., 1997; K1lıç, 2016), and the lowest reliability value was measured in the activities and precautions scale $(\alpha=0,834)$, and highest in the perceived success of crisis management $(\alpha=0.963)$. The lowest variance extracted was measured as $71 \%$ in the environmental screening scale while highest as $87 \%$ in the preparation and planning scale. The lowest measured $\mathrm{R}^{2}$ value was in the financial precaution scale (0.09), while the highest in the perceived success of the management (0.79).

Discussion - Considering the seven scales obtained from this study and the model created with these scales, it is seen that financial precautions and retrenchment that widely practiced in crisis times are actually worsen the impact of the crisis on the organizations, while production, sales and marketing activities eliminate the reverse effects of the crisis. It is also observed that the financial measures also negatively affect the perceived success of both the applications and the management in crisis time, and the production, sales and marketing have a positive effect. Considering the estimation power of preparatory activities carried out before and during the crisis $\left(R^{2}=0.60\right)$, it turns out that environmental scanning mostly affects this this phase.

\section{GíRIŞ}

Küreselleşen ve gitgide birbirine bağımlı hale gelerek hayatın her alanında ama özellikle de ekonomik, sosyal, hukuki ve siyasi alanlarda daha girift bir yapıya bürünen iş dünyasında, olumsuzluklar birbiri ardına yaşanmakta ve yaşanmaya da devam edecektir. Bunun sonucu olarak da herhangi bir bölge ya da ülkedeki olumsuzlukların kriz biçiminde diğer ülkelere yansımaları olmaktadır. Bu etkiler ve sonuçları ülkeden ülkeye, sektörden sektöre değişmekle birlikte tüm çalışma hayatını dolayısıyla da insanları etkilemektedir.

Örgütlerin yaşadığı her olumsuzluk kriz olarak değerlendirilmemekle birlikte, ancak örgütün varlığını tehdit eden, devamlılı̆̆ını sekteye uğratacak gelişmeler kriz olarak değerlendirilmektedir (Özdevecioğlu, 2002). Bununla birlikte krizin kaynağı ister yerel olsun isterse de global, ister doğal afet veya salgın isterse de rekabet veya yönetimden kaynaklanmış olsun, tüm krizlerin örgütlere yansımaları olmaktadır. Sebebi ne olursa olsun iyi yönetilemeyen krizlerin örgütlere yansımaları ve etkileri, gelir azalmasına bağlı kaynak sıkıntısı ve ekonomik kayıp olarak kendini göstermektedir. Bu kadar sık ve çok kriz yaşadıkları halde yaşadıklarından ders almayan örgütler, çoğu zaman ne yapacaklarını bilememekte ve aldıkları yanlış kararlarla hem kendi geleceklerini hem de ilişkide oldukları diğer örgütlerin geleceklerini tehlikeye atmaktadırlar.

Reel sektörün krizden ne derece etkilendiğini, durumunu belirten en önemli gösterge açllan ve kapanan şirket sayıları olduğu (Yıldırım, 2010:51) dikkate alınarak TOBB'un (2018) 2018 verileri incelenirse, 2018 yılında tasfiye olan firma sayısının, 2017'ye göre \%21,35 oranında artış kaydetmesinin en büyük sebeplerinden birinin kriz olduğu sonucuna varabiliriz. Nitekim uzmanlara göre de bunun sebebi 2018 yılında yaşanan finansal krizdir (ParaAnaliz, 2019). Yine 2007 yılında, önce Amerika Birleşik Devletleri'nde ortaya çıkan ve sonrasında da küresel çapta etkisini gösteren finansal kriz sebebiyle birçok ülke ekonomisi küçülmüş ve İstanbul Menkul Kıymetler Borsası ulusal para birimi cinsinden yaklaşık \%57 değer kaybetmiştir (Kutlu ve Demirci, 2011). Türkiye'nin son 25 yılda yaşadığı 1994, 2000, 2001, 2008, 2011, 2018 ve en son 2020 krizleri dikkate alındığında, krizlerin sürekli hayatımızda olduğu görülebilir.

Literatürde yapılan taramada, krizin tüm evrelerinin ölçümlenip değerlendirileceği bir ölçeğe rastlanamaması sonucu bu çalışmaya karar verilmiştir. Çalışmamızda, hayatın bir gerçeği olarak sürekli yaşanmakta olan bu krizlerin yönetim sürecini ölçümleyebilecek ölçeklerin geliştirilmesi amaçlanmıştır. Çoğu zaman birinin etkisi bitmeden diğer bir krizin içerisinde kendilerini bulan örgütler açısından krizin doğru bir şekilde yönetilmesi hayati önem taşımaktadır. Geliştirilmesi hedeflenen ölçeklerin, krizin hem öncesi hem süreci hem de sonrasında yapılan yönetsel faaliyetleri ölçümlemesi, bu ölçeklerin kullanılarak yaşanan krizlerin tüm yönlerinin bilimsel çalışmalarda incelenebilmesine ve bu çalışmalardan elde edilecek sonuçlarla uygulamacılara yardımcı olunması hedeflenmiştir. 


\section{KRİZ YÖNETIMI}

Kriz, örgütlerin iç veya dış çevrelerinin öngörülmedik bir şekilde ve aniden olumsuz yönde değişmesiyle ortaya çıkan, örgütün geleceğini, fiziki ve mali durumunu tehdit eden ve acil ve duruma özel önlemler alınmasını gerektiren olaylar (Okumuş, 2003; Dinçer, 2000; Küçükaltan vd., 2006; İncaz, 2018) bütünü olarak tanımlanabilir. Krizin belirtileri önceden fark edilmemesi örgütler için tehdit oluştururken, fark edilip iyi değerlendirilmesi fırsat, değerlendirilememesi veya yönetilememesi ise çöküş anlamına gelebilecek bir durumdur (Akdağ, 2001).

Günümüzde gelişmiş bilişim teknolojileri sayesinde, geçmişte hazırlaması günlerce hatta bazen aylarca sürebilecek olan finansal, satış, rakip analiz gibi hem iç hem de diş çevre ile ilgili raporlar çoğu zaman bir düğme kadar uzağımızda durmakta ve birçoğu da gerçek zamanlı olarak hazırlanıp elde edilebilmektedir. Bu gelişen teknoloji sayesinde kriz oluşmadan önce belirtilerini tespit ve krizi tahmin edebilmek (Özdemir, 2014:87) hiçbir zaman olmadığı kadar mümkün olabilmektedir. Bu durum da örgütlerin kriz öncesi önlemlerini harekete geçirmede etkendir.

İç veya dış çevrede aniden ortaya çıkan ve örgütün geleceği açısından tehdit ve fırsat ihtiva eden, ama aynı zamanda da acil ve duruma özel önlemler alınmasını gerektiren krizler (Okumuş, 2003; Dinçer, 2000; Çiftçi, 2015; İncaz, 2018), kaynakları ve etkileri sebebiyle on farklı başlık altında toplanabilirler (Çiftçi, 2015): iEkonomik/finansal, ii- Siyasal/Politik, iii- Doğal afet, iv- Ekolojik, v-Biyolojik, vi- Sosyal, vii- Terör kaynakll, viii- Yönetimsel, ix- Teknolojik ve x- Etik/Ahlaki.

PwC'nin (2019) kırk üç ülkeden 2.000 şirket ve 4.500 krizi inceleyerek yapmış olduğu araştırma sonuçlarına göre krizleri en çok tetikleyen 10 sebep ve yüzdeleri Tablo 1'de verilmiştir:

Tablo 1. Krizi Tetikleyen Sebepler

\begin{tabular}{l|l|c||l|l|c}
\hline SN & \multicolumn{1}{|c|}{ Sebep } & S1klık & SN & \multicolumn{1}{|c|}{ Sebep } & S1klık \\
\hline 1 & Finansal/Likidite & $\% 23$ & 6 & Siber suç & $\% 16$ \\
\hline 2 & Teknolojik aksaklık & $\% 23$ & 7 & Doğal afet & $\% 16$ \\
\hline 3 & Operasyonda aksaklık & $\% 20$ & 8 & Yönetimde değissim & $\% 15$ \\
\hline 4 & Rekabet/Pazarda değişim & $\% 19$ & 9 & Tedarik zinciri & $\% 14$ \\
\hline 5 & Yasal/Uyum & $\% 16$ & 10 & Ürün hatası & $\% 14$ \\
\hline
\end{tabular}

Kaynak: PwC, 2019: 6

Finansal sebepler ilk sırada olmasına rağmen toplam içerisindeki payı nispeten daha azdır. Nitekim yine aynı araştırmaya katılanların yarısından fazlası (\%53) operasyonel, yaklaşık üçte biri de (\%33) teknolojik, yine yaklaşık üçte biri (\%29) insan kaynaklı kriz yaşadıklarını belirtmişlerdir. Ancak \%28'i finansal kaynaklı kriz deneyimlemişlerdir (bkz. Tablo 2). Bu da göstermektedir ki yaşanan krizlerin ana sebepleri arasında finanstan ziyade diğer sebepler gelmektedir.

Tablo 2. Yaşanan Krizlerin Kaynakları

\begin{tabular}{l|l|c}
\hline \multicolumn{1}{c|}{ SN } & Sebep & S1klık \\
\hline 1 & Operasyonel & $\% 53$ \\
\hline 2 & Teknolojik & $\% 33$ \\
\hline 3 & İnsani & $\% 29$ \\
\hline 4 & Finansal & $\% 28$ \\
\hline 5 & Yasal & $\% 24$ \\
\hline 6 & İnsan Kaynakları & $\% 21$ \\
\hline 7 & İtibar & $\% 20$ \\
\hline
\end{tabular}

Kaynak: PwC, 2019: 6

Krizlerin bir kısmı öngörülebilmekteyken bazısını öngörmek zordur (Küçükaltan vd. 2006) ama yine de örgütlerin çoğu geleceğinden emin oldukları krizlere karşı bile hazırlıksızdırlar. 2019 yılı ekonomik göstergeleri, kamu ve özel borç stokunun yüksekliğine ve bunun bir krizi tetikleyebileceğine işaret etmekteyken fazla dikkate alınmaması (Mert ve Alan, 2020), sonrasında ise hızla yayılan COVID-19 salgınıla 


\section{Aslan - D. Küçükaltan - D. Uzun 12/3 (2020) 2382-2406}

derinleşen krizde de görmek mümkündür. Onlarca yıldır uzmanlar salgın konusunda uyarılar yapmasına (Henig, 2020), ilk vakanın duyurulduğu Aralık 2019 tarihinden (WHO, 2020) Avrupa'ya ulaştığı Şubat 2020 sonu (Monella, 2020) ve Türkiye' de görüldügü 10 Mart 2020 tarihine (Sağlık Bakanlığı, 2020) kadar iki aydan fazla bir süre olmasına rağmen ister kamu ister özel sektör, isterse de sivil toplum kuruluşu olsun, dünyanın neredeyse tümünde yeterli tedbir alınmadığı, hazırlık yapılmadığı ortaya çıkmaktadır (Henig, 2020). COVID19 salgını kadar tehlikeli boyutlara gelmiş olmasa da geçmişte yaşanmış olan H5N1 salgınında dünya hazırlıksızdı (Christophersen ve Haug, 2007).

Penrose'un (2000:155) yaptığı araştırmada, Fortune 1000 firmaların \%40'ının, diğer firmaların da yaklaşık \%80'ninin bir kriz yönetim planlarının olmadığını ortaya koymuştur. Ernst \& Young'ın 2020 yılında, 500 Yönetim Kurulu üyesi ve CEO'nun katılımı ile yaptığı araştırmada, katılımcıların \%80'ni, örgütlerinin krizlere gerektiği gibi hazırlık yapmadığını belirtmiştir (Herlant, 2020). Yirmi yıl arayla yapılmış bu iki çalışma, aslında krizlere hiçbir hazırlık yapılmadığının ve krizlerin hafife alındığının bir göstergesidir.

İlk tahminleri 2006 ve belirtileri 2007 yılı yazında görülmeye başlanan 2008 finansal krizi (Bezemer, 2009; Ferik, 2015) karşısında yine örgütler bir şey yapmamışlar ve sonuçta sadece Amerika'da yirmi beş banka, binlerce işletme tasfiye olmuş ve krizin maliyeti bir trilyon doları geçmiştir (Russo ve Katzel, 2011). Bu hazırlıksız yakalanma da kriz sürecinin yönetimine etki etmektedir. Bu sebepten dolayıdır ki kriz sürecini atlatabilmek için örgütlerin yaklaşık dörtte üçü (\%74) dışarıdan yardım almaktadırlar ( $\mathrm{PwC}, 2019)$. PwC'nin (2019) hazırladığ üstlenilen rollere bakıldığında; çevresel tarama, krize hazırlık, planlama, sahiplenme ve yönetme, iletişim konularında üst düzey yöneticiler diğer seviyelerdeki yöneticilere nazaran daha fazla rol üstlendiği görülmektedir (bkz. Tablo 3).

Tablo 3. Krizde Üstlenilen Rollerin Yönetici Seviyelerine Göre Dağılımı

\begin{tabular}{c|c|c|c|c|c}
\hline \multicolumn{2}{c|}{ Krize hazırlıklı olma } & \multicolumn{2}{|c|}{ Krize müdahale } & \multicolumn{2}{c}{ Paydaș iletissimi } \\
\hline Üst düzey yönetici & Diğer & Üst düzey yönetici & Diğer & Üst düzey yönetici & Diğer \\
\hline$\% 42$ & $\% 25$ & $\% 41$ & $\% 24$ & $\% 39$ & $\% 20$ \\
\hline
\end{tabular}

Kaynak: PwC, 2019: 9

Tablodan da anlaşılabileceği üzere; krize hazırlıklı olma safhası dahil tüm kriz yönetim safhalarında üst yönetimin üstlendiği rol öne çıkmakta ve bu noktada üst yönetimin etkili koordinasyonu, iletişimi, zamanında ve doğru kararlar alabilme becerileri önemli rol oynamaktadır. Dolayısıyla kriz sürecinde hem nesnel hem de algısal bir yönetim söz konusudur. Nitekim kriz yönetiminde algı hem krize hazırlık hem yönetim süreçlerinde hem de krizin sonuçları üzerinde etkili olmaktadır (Penrose, 2000). Tüm bunlar kriz yönetiminin iki ayaklı bir yapıya sahip olduğu sonucunu çıkarmamıza neden olmaktadır:

1- Gerçekte yapılan uygulamalar, bu uygulamaların sonuçları ve etkileri.

2- Kriz uygulamalarının algılanma şekli ve bunun sonucunda oluşan kriz yönetiminin algılanan başarısı.

Bunlardan birincisi, kapanan firma sayıları (TOBB, 2018) veya düşen borsa değerleri (Kutlu ve Demirci, 2011) gibi rakamsal olarak gösterilebilmektedir. Ama ikincisi ise hem paydaşların yapılan uygulamaların etkinliğini, başarıya etkisini ve bu uygulamaların sonuçlarını yani yönetimin süreci ne kadar başarıyla yürüttüğüne yönelik algılarını göstermektedir (Penrose, 2000:156).

Özdemir (2014:87) krizi Sinyal İzleme, Hazırlık/Önleme, Hasarı Azaltma, Yeniden Toparlanma ve Öğrenme olmak üzere 5 safhada incelemektedir (Özdemir, 2014: 87). Ölçeği geliştirirken bu beş safhayı çevresel tarama, hazırlık, krizin etkilerini azaltma faaliyetleri, krizin etkilerinin değerlendirilme ve öğrenme ya da krizden öğrenilenlerin uygulama safhası olarak ele almaktayız. Bu safhaları kısaca açıklamak gerekirse:

i. Kriz öncesinde sürekli yapılan çevresel tarama ile krizi önceden tahminleme safhası,

ii. Kriz ortaya çıtı̆̆̆ında krizin boyutları, olası etkileri ve yapılması gerekenlerin tartışıldığı tespit ve planlama ya da daha kısa tanımla hazırlık safhası,

iii. Yapılan planlama doğrultusunda alınan tedbirler, gerçekleştirilen faaliyetlerin olduğu safha. 


\section{Aslan - D. Küçükaltan - D. Uzun 12/3 (2020) 2382-2406}

Kriz yönetiminde ise bu safhada tüm paydaşlarda uygulamaların olası başarı ya da başarısızlığa yapacağı muhtemel katkılar ve geçmişte yapılmış olan çevre tarama faaliyetleri ile hazırlık ve planlama faaliyetlerinin ne derece sağlıklı ve başarılı yapıldığı yönünde algılar oluşmaya başlar.

iv. Kriz sonrasında örgüt üzerindeki etkilerinin incelendiği durum değerlendirme ya da krizin etkilerinin değerlendirilmesi safhası.

Algılanan kriz yönetiminde ise bu safhada yönetimin hangi konuda ne derece etkin ve başarılı olduğu yönünde algı oluşur.

v. Kriz yönetimi süresince ve sonrasındaki değerlendirmelerden elde edilen veriler ışığında örgüt yapısı ve süreçlerinde yapılan değişikliklerle bir sonraki krize karşı direnç geliştirmenin olduğu krizden öğrenilenlerin uyarlanması safhası. Bu safhada uyarlamaların sağlıklı ve başarılı olabilmesi için yapılacak değişikliklerin kriz yönetiminin algılanan başarısında etkin rol oynamış olması gerekmektedir.

Tablo 4. Kriz Safhaları

\begin{tabular}{c|c|c}
\hline Safha & Uygulanan Kriz Yönetimi & Algılanan Kriz Yönetimi \\
\hline 1 & \multicolumn{2}{|c|}{ Çevresel Tarama } \\
\hline 2 & Hazırlik ve Planlama \\
\hline 3 & Faaliyetler ve Tedbirler & Kriz Süresince Yapılan Uygulamaların, Kriz \\
\hline 4 & Krizin Etkilerinin Değerlendirilmesi & Yönetimin, Krizi Yönetmedeki Algılanan Başarıs \\
\hline 5 & \multicolumn{2}{|r}{} \\
\hline
\end{tabular}

Beşinci safhadan sonra örgüt tekrardan birinci safhaya dönüş yaparak, çevresel tarama süreci safhasına geçer ve bir sonraki krize ait ipuçlarını elde etmeye çalışır. Bu durumu bir akış üzerinde göstermek gerekirse Şekil 1 elde edilir.

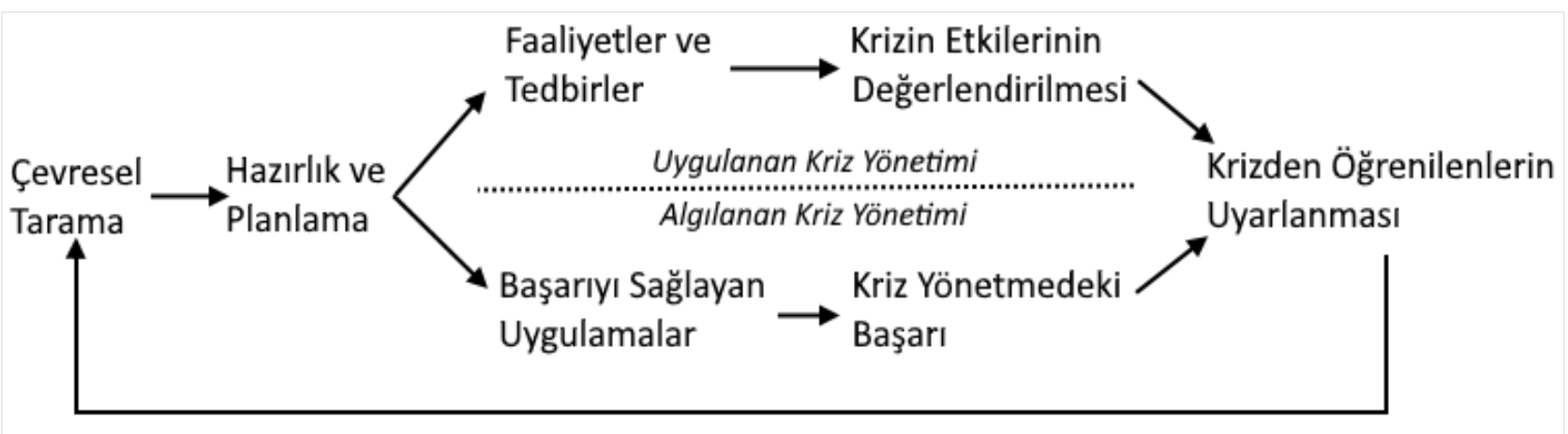

Şekil 1. Kriz Süreci

\section{1. Çevresel Tarama Süreci}

Çevresel tarama, ister kâr amaçlı olsun veya olmasın tüm örgütler için hayati önem taşıyan bir süreçtir (Albright, 2004; Abu Amuna vd., 2017). Çevresel tarama süreci hem diş çevrenin hem de iç çevrenin olası riskler, fırsatlar, tehditler ve değişimlerin önceden belirlenmesi ve bunlara karşı zamanında ve gerekli tedbirlerin alınmasını sağlar. Dış çevrenin taranması tehditler ve fırsatları ortaya koyarken, iç çevre analizi de örgütün güçlü ve zayıf yanlarının tespit edilmesini sağlar (Albright, 2004; Akdemir ve Konakay, 2016; Ürü San1, 2018).

Dış çevre politik, yasal, ekonomik, sosyokültürel, teknolojik, uluslararası, sektörel, demografik ve doğal çevre olarak sinıflandırılabilir (Ülgen ve Mirze, 2011; Yiğit ve Yiğit, 2011; Abu Amuna vd., 2017). Bunlar da kendi içinde genel/uzak çevre ve sektör/iş çevresi (Ülgen ve Mirze, 2011) olarak sinıflandırılabilir. İç çevre olarak kaynaklar, kapasite, yetkinlikler, örgüt kültürü, örgüt yapısı, yönetim stili sayılabilir (Adnan, 2015; Abu Amuna, 2017). 


\section{Aslan - D. Küçükaltan - D. Uzun 12/3 (2020) 2382-2406}

Çevresel tarama sürecinde dış ve iç çevre sürekli gözlenerek, önceden belirlenmiş olan bazı parametrelerdeki değişimler, normal dönemdekilerle sistematik olarak karşılaştırılır ve farklı olup olmadıkları, çeşitli parametrik ve parametrik olmayan testler kullanılarak değerlendirilerek (Şen, 2005:104; Büyükakın ve Aydın, 2018:113-118) olası krizler veya en azından değişimlerin yönü ve etkileri tahmin edilmeye çalışılır.

\subsection{Hazırlık Safhası}

Kriz hazırlık safhası kriz ortaya çıktığında, gelişme dönemine girmeden atlatılmasını hedeflerken (Köroğlu, 2004), her olasılığa karşı planların hazırlandığı, önlemlerin tartışıldığı ve tüm paydaşlarla iletişimin gerçekleştirildiği safha olup genelde 6-10 kişilik takımdan oluşur (Penrose, 2000). Bu kriz yönetim takımının içerisinde CEO dahil tüm birimlerden karar verici pozisyonda olan yöneticilerle hukukçular bulunurlar (Mitroff vd., 1987; Reilly, 1993; Penrose, 2000; Shi ve Cui, 2011). Hazırlık ve planlama safhası aynı zamanda iletişim, paydaşların bilgilendirilmesinin ve birimler, çalışanlar arasında koordinasyonun en üst düzeyde gerekli olduğu safhalardan biridir (King, 2002; Shi ve Cui, 2011; Reilly, 1993) çünkü krizin boyutlarının ele alındığı ve önlemlerin, üstesinden gelinecek eylemlerin, tedbirlerin tartışılıp karar verildiği safhadır.

$\mathrm{Bu}$ safhada mümkünse krizi fırsata dönüştürmenin, değilse de en az hasarla atlatmanın yolları aranır, uygulamalar ve tedbirler planlanır. Araştırmalar göstermektedir ki krize hazır olma durumu krizin örgüte verdiği hasarı azaltmakta hatta yeni fırsatlar yaratabilmeyi sağlamaktadır (Arslan, 2009:181).

\subsection{Faaliyetler ve Tedbirler Safhası}

Hazırlık safhasında yapılmış olan kriz yönetim ve faaliyet planlarının uygulanmaya koyulduğu, sonuçlarının çok sık ve sürekli değerlendirilerek gerekli düzeltme ve değiştirmelerin yapıldığı, kriz yönetiminin en önemli safhalarından biridir. Bu safha sektörden sektöre ve firma büyüklüğüne göre değişmekle birlikte, örgütler genellikle insan kaynakları dâhil tüm kaynak kullanımlarında tasarrufa gitmeye, pazarlama faaliyetlerini arttırmaya, maliyetlerini düşürmeye, stratejik ortaklıklar oluşturulmaya ve mümkün olduğunca ödemeleri ötelemeye ve tahsilatları öne çekmeye çalışmaktadırlar (Israeli ve Reichel, 2003; Köroğlu, 2004). Yine bu safhada, krizin boyutlarına bağlı olarak, merkezi yönetimden teşvik beklentileri oluşmakta (Karakurt, 2010), bu süreçte verilen devlet destekleri, örgütlerin yukarıda sayılan önlemleri hangi oranda ve ne kadar süreyle uygulayacakları konusunda belirleyici olmaktadır.

Bunun en son örneği, yukarıda verilen Aralık 2019`da Çin' de başlayıp 3 ay gibi bir süre içerisinde tüm dünyayı etkisi altına alan COVID-19 salgını karşısında devletlerin sunduğu destek paketleridir (PwC, 2020; TOBB, 2020; Altaş, 2020). Bu bağlamda Türkiye 100 milyar TL tutarında bir destek paketi açıklarken (Altaş, 2020) başta Amerika açıkladığı bir trilyon dolarlık paket ile başı çekmektedir (Radu, 2020). Diğer ülkelerin her biri de nüfuslarına ve ekonomik büyüklüklerine göre milyarlarca dolarlık ekonomik destek paketleri açılamakta ve süreç içerisinde bu paketlerin içeriğini hem çeşitlendirmekte hem de kapsamını genişletmektedirler (Radu, 2020).

Bu safha aynı zamanda çevresel tarama ve bu tarama sonucunda elde edilen bilgiler, veriler ışığında uygulamalarda değişikler yapıldığı safhadır. Özellikle krizde olan diğer örgütlerin veya krizi atlatmış olan örgütlerin yaptıkları doğru ve yanlış uygulamaların bir şekilde kıyaslama (benchmarking) yöntemi ile örgüt yapısına, stratejisine ve etki düzeyine göre alındığı, uyarlandığı görülmektedir (Jaques, 2008:198). Stratejik dayanışma ve ortaklıkların, bilgi ve teknoloji paylaşımlarının en çok görüldüğü safhalardan biri de bu safhadır (Richardson, 1994:72; Starosta, 2014:260). Çünkü uygulamaların hangilerinin menfi ya da müspet sonuçlar verdiği bu safhada şekillenmeye başlamakta ve bu bağlamda bilgi birikimi oluşmaktadır. Tüm bu süreçte en önemli olan noktalardan biri de insanların kriz ve etkileri hakkındaki algılarıdır. Bu algılar hem hazırlık hem de uygulama safhalarını, kriz hazırlık planlarını yüksek düzeyde etkilemektedir (Penrose, 2000).

\subsection{Durum Değerlendirme Safhası}

Krizler bir örgütün finansal yapısını, itibarını, çalışanlarını, ürettiği mal ve hizmetleri derinden etkileyebilen olaylardır (King, 2002). Bu safhada, krizden sonra örgütün durumu değerlendirilmektedir. Yapılan doğrular ve hatalar, etkili olan stratejiler ve uygulamaların değerlendirildiği, yazılı hale getirildiği safhadır (Mitroff vd., 1987). PwC (2019) yaptı̆̆ı araştırma sonuçlarında krizin iş ilişkilerine, itibara, çalışanların moral ve motivasyonuna, yasal/uyum problemlerine etkisi tespit edilmiştir. Yine aynı araştırmaya göre en büyük etki \%57 ile ekonomik kayıp olmaktadır (PwC, 2019). 


\subsection{Değişim, Uyarlama Safhası}

Durum değerlendirme safhasından elde edilen bilgiler ve kriz sürecinde öğrenilenlerin örgüt yapısına, iş planına ve tüm süreçlerine uyarlanması ve uygulanması aşamasıdır. Bu safha örgütsel öğrenme, değişim aşaması olup, örgütün öğrendikleriyle geleceği şekillendirme ve bir sonraki krize hazırlık yapma aşamasıdır (Mitroff vd., 1987). Bu safhayı gerektiği gibi uygulayamayan, yapılan hatalardan öğrenip gerekli eylem planlarını uygulayamayan veya eski bildiği yanlışları unutamayan örgütlerin aynı hataları yapması kaçınılmaz olmaktadır (Sheaffer ve Mano-Negrin, 2003; Mitroff vd., 1987). Bu safhaya etki eden en önemli değişkenlerden biri de örgüt genelinde kriz süresince yapılan faaliyetlerle alınan tedbirlerin ve yönetimin ne derece başarılı olduğu algısıdır.

\section{YÖNTEM}

\subsection{Katılımcilar}

Ölçek geliştirilmesi sürecinde son teste çeşitli sektörlerde yönetici pozisyonunda çalışan toplam 188 kişi katılmış, karara etki düzeyi hiç olmayan veya az olan toplam 35 kişi değerlendirme dışı bırakılmıştır. Tüm analizler 153 katılımcıdan elde edilen verilerle gerçekleştirilmiştir (Tablo 5). Faktör yüklerinin 0,50' den büyük olduğu durumlarda örneklem büyüklüğünün 150-200 arasında olmasının yeterli olduğu (Worthington ve Whittaker, 2006) ve daha fazla örnekleme gerek olmadığı kabul edilmiştir.

Veriler 2020 yılı öncesinde toplandığından dolayı etik kurul izni alınmamıştır.

Tablo 5. Katılımcıların Demografik Özellikleri

\begin{tabular}{|c|c|c|c|c|c|c|c|}
\hline Özellik & Gruplar & $\mathrm{f}$ & $\%$ & & Gruplar & $\mathrm{f}$ & $\%$ \\
\hline \multirow{5}{*}{ Yaş } & 35 Yaş altı & 16 & 10,50 & \multirow[t]{8}{*}{ Poziyon } & İşletme Sahibi/Ortağı & 34 & 22,22 \\
\hline & $\begin{array}{l}\text { 35-44 Yaş } \\
\text { aras1 }\end{array}$ & 51 & 33,30 & & YKB & 1 & 0,65 \\
\hline & $\begin{array}{lr}45-54 & \text { Yaş } \\
\text { arası }\end{array}$ & 59 & 38,60 & & CEO & 1 & 0,65 \\
\hline & 55 ve üzeri & 27 & 17,60 & & Genel Müdür veya GM Yrd. & 17 & 11,11 \\
\hline & Toplam & 153 & 100,00 & & Direktör/Koordinatöre & 30 & 19,61 \\
\hline \multirow{3}{*}{ Cinsiyet } & Erkek & 106 & 69,30 & & Departman Mdr./Mdr. Yrd. & 52 & 33,99 \\
\hline & Kadın & 47 & 30,70 & & Diğer Alt Düzey Yöneticiler & 18 & 11,76 \\
\hline & Toplam & 153 & 100,00 & & Toplam & 153 & 100,00 \\
\hline \multirow{7}{*}{$\begin{array}{l}\text { Eğitim } \\
\text { Düzeyi }\end{array}$} & İlkokul & 1 & 0,70 & \multirow{6}{*}{$\begin{array}{r}\text { Alınan } \\
\text { Karara } \\
\text { Etki }\end{array}$} & Karar grubundakilerden biraz az & 36 & 23,50 \\
\hline & Lise & 17 & 11,10 & & Karar grubundakilerle aynı & 33 & 21,60 \\
\hline & Ön Lisans & 10 & 6,50 & & Karar grubundakilerden fazla & 22 & 14,40 \\
\hline & Lisans & 74 & 48,40 & & Yüksek & 47 & 30,70 \\
\hline & Yüksek Lisans & 43 & 28,10 & & Kararları ben alırım & 15 & 9,80 \\
\hline & Doktora & 8 & 5,20 & & Toplam & 153 & 100,00 \\
\hline & Toplam & 153 & 100,00 & & & & \\
\hline
\end{tabular}

\section{2. İşlem}

$\mathrm{Bu}$ ölçek geliştirme çalışmasında literatür taraması, akademisyenler ve çeşitli sektörlerdeki yöneticilerle görüşülerek 80 ifadeden oluşan bir havuz oluşturulmuştur. Bu ifade havuzu farklı üniversitelerin işletme bölümlerinde görev yapmakta olan beş farklı akademisyene, farklı sektörlerde görev yapmakta olan 10 yöneticiye ve hem çalışma hayatında yöneticilik yapmakta olan hem de akademisyen olan 5 farklı kişiye gönderilerek her bir ifadeden ne anladıkları ve ifadenin nasıl olması gerektiği yönünde tavsiyeleri alınmıştır. Seksen ifadeli havuz bazı ifadeler birleştirilerek, bazıları da çıkartılarak önce 74 ifadeye düşürülmüş ve aynı kişilere tekrar gönderilmiştir. Gelen geri bildirimler ışığında ifade sayısı yine birleştirilerek ve elenerek 58 ifadeye düşürülmüş, son hali aynı kişilere tekrar gönderilerek görüşleri istenmiştir. Elde edilen son hali 7'li Likert ölçek (Trochim, 2020) olarak düzenlenmiş ve saha çalışmasına başlanmıştır. 


\section{Aslan - D. Küçükaltan - D. Uzun 12/3 (2020) 2382-2406}

Ölçek geliştirilmesi sürecinde ilk teste çeşitli sektörlerde yönetici pozisyonunda çalışan toplam 85 kişi katılmıştır. Yapılan faktör analizinde boyutların oluştuğu ve bazı ifadelerin herhangi bir boyut altında toplanmadığı müşahede edilmiş ve bu ifadeler çıkartıldıktan, bazı ifadeler ise birleştirildikten sonra elde edilen toplam 47 ifadeden oluşan ölçek ile ikinci test çalışması yapılmıştır. İkinci test toplamda 188 katılımcı ile gerçekleştirilmiştir. Katılımcıların 35'inin alınan kararlara etki düzeyi hiç yok veya çok az olduğundan bu anketler analiz dışı bırakılmış ve toplamda 153 katılımcıdan elde edilmiş verilerle analiz gerçekleştirilmiştir.

\subsection{Analiz}

Ölçeklerin geçerlilik ve güvenirlilik analizleri kapsamında öncelikle Keşfedici Faktör Analizi (Exploratory Factor Analysis - EFA) çalışmaları gerçekleştirilmiştir daha sonra faktörlerin iç tutarlılıklarını belirlemek amacıyla güvenilirlik analizleri yapılmıştır. Araştırmanın keşfedici faktör analizleri ve güvenilirlik analizi çalışmaları SPSS 21.0 yazılımı ile gerçekleştirilmiştir. Araştırma kapsamında kullanılan tüm istatistiksel analizlerde anlamlllık düzeyi 0,05 olarak kabul edilmiş ve elde edilen tüm sonuçlar çift yönlü olarak sınanmıştır. Tüm faktör analizlerinde Temel Bileşenler Yöntemi (Principal Component Analysis) kullanılmıştır. Faktör sayılarını belirlemek için herhangi bir döndürme yöntemi kullanılmamış, ancak faktör sayıları belirlendikten sonra Direct Oblimin Döndürme Yöntemi (Oblimin with Kaiser Normalization Rotation Method) kullanılarak faktör analizi yapılmıştır (Carpenter, 2018).

Veri setinin faktör analizine uygunluğunun test edilmesi için, Kaiser-Meyer-Olkin (KMO) örneklem yeterliliği testi ve Bartlett Küresellik Testi (Bartlett's Test of Sphericity) uygulanmıştır (Carpenter, 2018). KMO değerinde aranan kriter değerin 0,50'den büyük olması ve Bartlett test sonucu da anlamlı çıkması (Fields, 2002; Sarstedt ve Mooi, 2014; Carpenter, 2018) olduğu halde, KMO değerinin yorumlanması Tablo 6 kullanılarak yapılmıştır ve KMO değerinin 0,60'tan büyük olması kriter olarak kabul edilmiştir.

Tablo 6. KMO Eşik Değerleri

\begin{tabular}{lll|l}
\hline KMO Değeri & Yorumlama & KMO Değeri & Yorumlama \\
\hline$<0,50$ & Kabul Edilemez & $0,70-0,79$ & İyi \\
\hline $0,50-0,59$ & Kötü & $0,80-0,89$ & Çok İyi \\
\hline $0,60-0,69$ & Vasat & $>0,90$ & Muhteşem \\
\hline
\end{tabular}

Kaynak: Sarstedt ve Mooi 2014:208

Veriler ait oldukları ölçekler uyarınca gruplandırıldıktan sonra faktör analizine uygun olup olmadıkları test edilmiştir. Faktör analizine uygunlukta her bir ifadenin korelasyon değerlerine bakılmış ve korelasyon eşik değer 0,90 (Field, 2018) olarak kabul edilmiştir. Tabachnick ve Fidell (2013) ifadeler arasında oluşturulan korelasyon matrisinde determinantın sıfıra yakın olma seviyesi çoklu doğrusal bağlantı sorununun o derece varlığına işaret ettiğini belirtmektedir. Bu sebepten dolayı determinant değerinin 0,00001'ten büyük olması çoklu doğrusal bağlantı (collinearity) kriteri olarak alınmıştır (Field, 2018). Ayrışma geçerliliği ölçütü olarak da korelasyon matrisinde her bir ifadenin bir tek faktör altında toplanması, faktörlerin çapraz yük almaması ve bir diğer faktör altında bulunan faktör yükü değerinin 0,70'ten küçük olması (Field, 2018) alınmıştır.

Her bir ifadenin tek tek uygunluklarında da 0,50 kritik değer olarak alınmıştır. Bu değerin altında kalan ifadeler araştırmadan çıkarılıp ve faktör analizine o şekilde devam edilecektir. Ters imaj korelasyonunda da bu değer $(0,50)$ kritik değer olarak kabul edilmiş ve bu değerin altında kalan ifadeler araştırmadan çıartılacaktır (Hair vd., 2010). Her bir ölçeğin faktör analizi sonucunda açıklanan ortalama varyans değerinin de $\geq 0,50$ olarak gerçekleşmesi beklenmektedir (Field, 2018).

Her ne kadar ölçek geliştirme çalışmalarında, Keşfedici Faktör Analizi (EFA) sonucunda bulunan boyutları teyit etmek için farklı bir örneklem ile Doğrulayıcı Faktör Analizi (CFA) kullanılması tavsiye edilse de (Cabrera-Nguyen, 2010; Yaşlığlu, 2017), sadece EFA kullanılmasının da yeterli olduğu (Kline, 2005 aktaran Cabrera-Nguyen, 2010) göz önünde bulundurularak çalışmamızda sadece EFA kullanılmıştır.

Faktör sayısı tespit edilirken rakamsal olarak Eigen değeri (Eigen değeri $>1$ ), görsel olarak da scree plot grafiği ve faktörler altında toplanan ifadelerin de aynı kavram ile ilişkili olması referans olarak alınmıştır. Her bir faktör altında toplanan ifadelere bakılarak boyutların isimlendirmesi yapılmıştır. Kriz yönetim süreci ölçeklerimiz toplam yedi adet olup bunlar: 


\section{Aslan - D. Küçükaltan - D. Uzun 12/3 (2020) 2382-2406}

Tablo 7. Geliştirilen Kriz Yönetim Süreci Ölçekleri

\begin{tabular}{|c|c|c|}
\hline SN & Ölçek Adı & Açıklama \\
\hline 1 & Çevresel Tarama & $\begin{array}{l}\text { Kriz öncesi yapılmış olan çevresel tarama ile önceki krizlerden elde } \\
\text { edilmiş olan bilgiler ışı̆̆ında alınan aksiyonlar. }\end{array}$ \\
\hline 2 & Hazırlık ve Planlama & $\begin{array}{l}\text { Kriz ilk ortaya çıktığında yapılan değerlendirme, planlama çalışmaları } \\
\text { ve paydaşlarla iletişim }\end{array}$ \\
\hline 3 & Faaliyetler ve Tedbirler & $\begin{array}{l}\text { Kriz süresince yapılmış olan geliştirme, iyileştirme faaliyetleri dâhil } \\
\text { üretim, satış ve pazarlama faaliyetleriyle finansal yapılandırmalarla } \\
\text { tasarruf tedbirleri. }\end{array}$ \\
\hline 4 & $\begin{array}{l}\text { Krizin } \\
\text { Yansımaları/etkileri }\end{array}$ & $\begin{array}{l}\text { Kriz sonrasında yapılan değerlendirmeler sonucunda tespit edilen } \\
\text { örgütün pazar payının, itibarının ve büyüklüğünün etkilenme düzeyi }\end{array}$ \\
\hline 5 & $\begin{array}{l}\text { Krizde Yönetimin } \\
\text { Başarısı }\end{array}$ & $\begin{array}{l}\text { Kriz yönetimi süresince yönetimin bir bütün olarak hangi konularda } \\
\text { başarılı olduğuna yönelik katılımcıların algiları. }\end{array}$ \\
\hline 6 & $\begin{array}{l}\text { Başarıyı Etkileyen } \\
\text { Uygulamalar }\end{array}$ & $\begin{array}{l}\text { Kriz süresince yönetimin yapmış olduğu uygulamalar ve bunların kriz } \\
\text { yönetimindeki başarıya etkileri konusunda katılımcıların algıları }\end{array}$ \\
\hline 7 & $\begin{array}{l}\text { Krizden Öğrenilenlerin } \\
\text { Uyarlanması }\end{array}$ & $\begin{array}{l}\text { Kriz sonrası yapılan değerlendirmeler ve kriz süresince elde edilen } \\
\text { tecrübeler sonucunda örgüt yapısında, iş planında, ürünlerinde ve } \\
\text { yönetim dahil işleyişinde meydana gelen değişiklikler. }\end{array}$ \\
\hline
\end{tabular}

Cronbach alfa değerinin yorumlanmasında da aşağıdaki tablo kullanılmıştır (Kılıç, 2016).

Tablo 8. Cronbach Alfa Güvenilirlik Katsayıları ve Yorumlama

\begin{tabular}{l|l||l|l}
\hline Cronbach $\alpha$ & Yorum & Cronbach $\alpha$ & Yorum \\
\hline$\geq 0.9$ & Mükemmel & $0.6 \leq \alpha<0.7$ & Kabul edilebilir \\
\hline $0.7 \leq \alpha<0.9$ & İyi & $0.5 \leq \alpha<0.6$ & Zaylf \\
\hline & & $\alpha<0.5$ & Kabul edilemez \\
\hline
\end{tabular}

Kaynak: K1lıç, 2016:48

\subsection{1. Çevresel Tarama Ölçeği}

Çevresel tarama ölçeğinde ifadeler 2 alt boyutu ölçmek için hazırlanmıştır. Bu alt boyutlar:

i- $\quad$ Dış Çevre: Rakiplerin ve olası rakiplerin faaliyetlerinin, müşteri talep ve tercihlerinin, pazardaki üretim/hizmet ve ürünlerle ilgili faaliyet ve gelişmelerin ne derece takip edildiği ölçümlenmeye çalışılmıştır. Buna ilave olarak sektörel, teknolojik, hukuki, siyasi ve ekonomik gelişmelerin ne derece takip edildiği ve bunların olası etkilerinin ne derece analiz edildiği de tespit edilmeye çalışılmıştır.

ii- $\quad$ İç Çevre: Bu boyut altında önceden yaşanmış krizlerden elde edilen bilgi ve tecrübelerin ne derece örgüte uyarlandığı ne derece bu yaşanmış krizlerden elde edilmiş tecrübelere dayanılarak tedbir alındığı, krizi neden olabilecek personel ve müşterilerden kaynaklanan problemler dahil örgütsel, finansal ve yönetsel yapı, üst yönetimin yetersizliği ve hataları, ürün ve üretim sürecinde karşılaşılan hatalar vb. krize sebep olabilecek dâhili unsurların ne derece tespit edilip önlem alındığı ölçümlenmeye çalışılmıştır.

Ölçeğimizin Kaiser-Meyer-Olkin (KMO) değerinin 0,930, Ki-Kare değerinin 982,619 ve Bartlett küresellik test sonucunun anlamlı $(\mathrm{p}=0,000)$ çıkması sebebiyle faktör analizine uygun olduğu sonucuna varılmış ve Keşfedici Faktör Analizi (EFA) yapılmıştır. Toplam 10 ifade ile ölçümlenmeye çalışan Çevresel Tarama, ilk testin ardından bazı ifadelerin herhangi bir faktör altında toplanmaması nedeniyle çıkartılmış, bazıları da birleştirilerek 8 ifadeye düşürülmüştür. Beklentinin aksine iki boyut yerine her iki testte de tek bir boyut elde edilmiştir. Bu durum Scree Plot grafiği ile de (bkz. Şekil 2) görsel olarak teyit edilmiştir. 


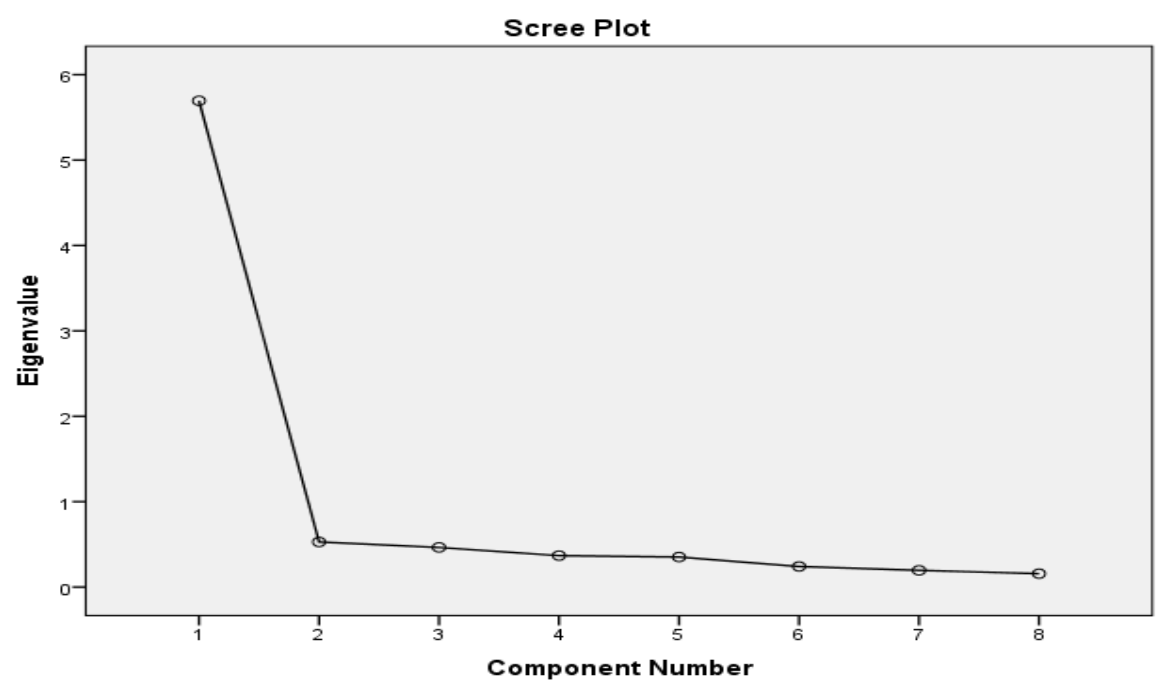

Şekil 2. Çevresel Tarama Ölçeğine Ait Scree Plot Grafiği

İkinci testin sonucunda elde edilen sonuçlar ve boyutlar: Elde edilen tek boyutun Eigen değeri 5,694 olup bir sonraki değer ise 0,528 . Dolayısıyla ölçeğin sadece bir tek boyutlu olduğu sonucuna varılmıştır. Ölçeğin determinant değeri 0,001>0,00001 olup ifadeler arasındaki korelasyon matrisinde tüm korelasyonlar 0,90'dan küçüktür. Ters imaj korelasyon tablosunda tüm ölçüm uygunluk değerleri (Measures of Sampling Adequacy - MSA) 0,50'dan büyük olup tespit edilen en küçük değer 0,896'dır.

Tüm bu veriler ışığında Çevresel Tarama ölçeğine ait faktör analiz sonuçları Tablo 9'da verilmiştir.

Tablo 9. Çevresel Tarama Ölçeği ve Alt Boyutlarının Faktör ve Güvenilirlik Analizi Sonuçları

\begin{tabular}{|c|c|c|}
\hline \multicolumn{3}{|c|}{ ÇEVRESEL TARAMA } \\
\hline$\alpha: 0,941$ & İfade Sayısı: 8 & Faktör Yükü \\
\hline \multicolumn{2}{|c|}{$\begin{array}{l}\text { Faaliyet gösterilen pazarda sektörel, siyasi, ekonomik gelişmeler ne ölçüde takip edilir, } \\
\text { pazara olabilecek olası etkileri analiz edilirdi? }\end{array}$} & 897 \\
\hline \multicolumn{2}{|c|}{$\begin{array}{l}\text { Faaliyet gösterilen pazarda talep ve tercihlerdeki değişimler ne ölçüde önceden araştırılıp } \\
\text { gerekli aksiyonlar alınırdı? }\end{array}$} & 886 \\
\hline \multicolumn{2}{|c|}{$\begin{array}{l}\text { Üretim, satıs, bakım/onarım, kaynak kullanımı, insan kaynakları vb. gibi raporlar ne } \\
\text { ölçüde hazırlanır, incelenir ve gerekli aksiyonlar alınırdı? }\end{array}$} & 871 \\
\hline \multicolumn{2}{|c|}{ Rakip ve olası rakiplerin faaliyetleri ne ölçüde takip ve analiz edilirdi? } & ,860 \\
\hline \multicolumn{2}{|c|}{$\begin{array}{l}\text { Önceden yaşanan krizlerden elde edilen tecrübeler ışığında, gerekli önlemler ne ölçüde } \\
\text { alınır ve uygulanırdı? }\end{array}$} & 825 \\
\hline \multicolumn{2}{|c|}{$\begin{array}{l}\text { Ne ölçüde üretim/hizmet dahil tüm faaliyetlerle ilgili gelişmeler takip edilir işletmenize } \\
\text { uyarlanırdı? }\end{array}$} & 820 \\
\hline \multicolumn{2}{|c|}{$\begin{array}{l}\text { İşletmeniz dâhilinde krize neden olabilecek potansiyel tehlike ve risklere (kaza, yangın, } \\
\text { çatışma, grev, geri dönüşü yüksek maliyetli yanlış veya hatalı üretim/tasarım vb.) karşı ne } \\
\text { ölçüde önlemler alınırdı? }\end{array}$} & 811 \\
\hline \multicolumn{2}{|c|}{ Ne ölçüde iç iletişime, çalışan ve paydaşlarla bilgi paylaşımına önem verilirdi? } & ,771 \\
\hline Kaiser-Meyer-Olkin: 0,930 & Chi Kare: 982,619 & Sig: 0,000 \\
\hline
\end{tabular}

Elde edilen ölçeğin Cronbach Alfa güvenilirlik katsayısı 0,941 olup Tablo 8'de verilmiş kriterler ışığında Mükemmel olarak yorumlanabilir. Tüm ölçeğin açıkladığı varyans ise yaklaşık \%71>\%50 olmaktadır ki bu da bir birimlik değişimin yaklaşık \%71'nin bu ifadelerle tespit edilebileceği anlamına gelmektedir.

\subsubsection{Hazırlık ve Planlama Ölçeği}

Hazırlık ve planlama ölçeğinde kriz ilk ortaya çıktığında ne ölçüde durum tespit ve planlamaların yapıldığı ölçümlenmeye çalışılmıştır. Bu durumun tespiti için 6 soru hazırlanmıştır. 


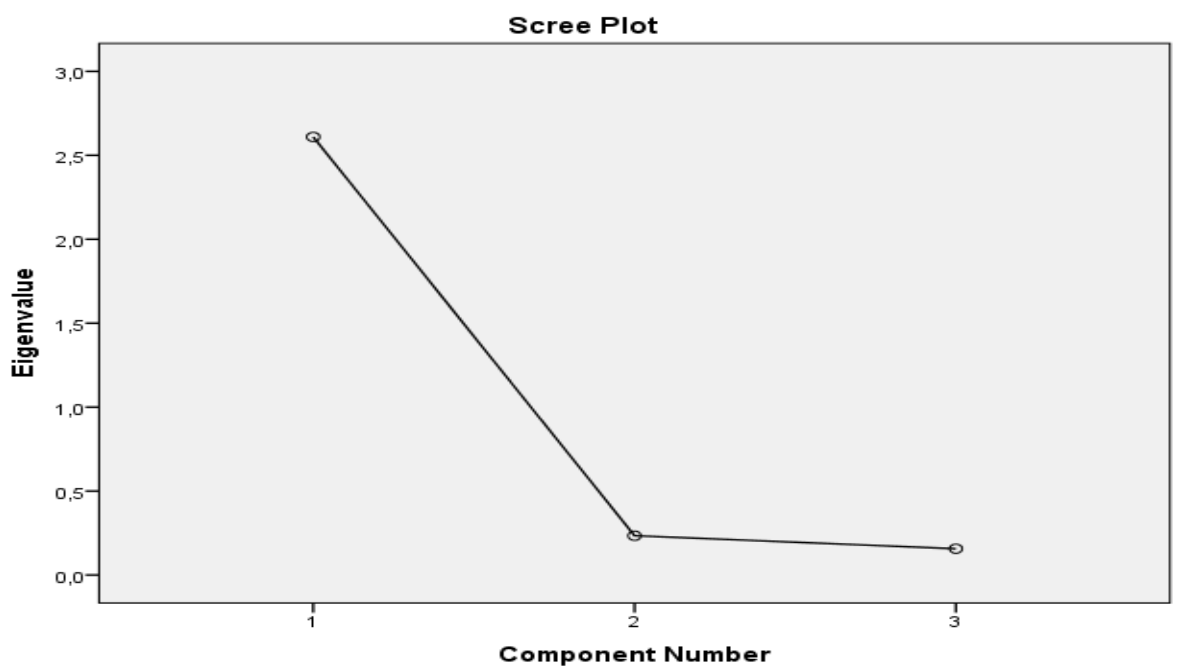

Şekil 3. Hazırlık ve Planlama Ölçeğine Ait Scree Plot Grafiği

Ölçeğimizin KMO değerinin 0,756, Ki-Kare değerinin 352,613 ve Bartlett küresellik test sonucunun anlamlı $(p=0,000)$ çıkması sebebiyle faktör analizine uygun olduğu sonucuna varılmış ve Keşfedici Faktör Analizi (EFA) yapılmıştır. Fakat ilk testten sonra bazı ifadelerin çapraz yük alması, bazılarının da herhangi bir faktör altında toplanmaması nedeniyle çıkartılmış, bazıları da birleştirilerek 3 ifadeye düşürülmüştür. Şekil 3'te verilen Scree Plot grafiğinden de anlaşıldığı üzere ölçeğimiz tek boyutlu olup boyuta ait Eigen değeri 2,610'dur. İkinci testin sonucunda elde edilen sonuçlar ise şöyledir: Ölçeğin determinant değeri 0,096>0,00001 olup ifadeler arasındaki korelasyon matrisinde tüm korelasyonlar 0,90'dan küçüktür.

Ters imaj korelasyon tablosunda tüm ölçüm uygunluk değerleri (MSA) 0,50'dan büyük olup tespit edilen en küçük değer 0,714'tür. Tüm bu veriler ışığında Hazırlık ve Planlama ölçeğinde sadece bir tek boyut elde edilmiş olup Tablo 10' da analiz sonuçları verilmiştir.

Tablo 10. Hazırlık ve Planlama Ölçeğinin Faktör ve Güvenilirlik Analizi Sonuçları

\begin{tabular}{|c|c|c|c|}
\hline \multicolumn{4}{|c|}{ HAZIRLIK ve PLANLAMA } \\
\hline$\alpha: 0,924$ & İfade Sayısı: & & Faktör Yükü \\
\hline \multicolumn{3}{|c|}{$\begin{array}{l}\text { Krizden çıkış için yapılması gerekenlerle ilgili takımlar oluşturuldu mu? ve gerekli } \\
\text { çalışmaları yapmaları ne ölçüde sağlandı? }\end{array}$} & ,945 \\
\hline \multicolumn{3}{|c|}{$\begin{array}{l}\text { Krizin boyutları, etkileri ve krizi aşmak için uygulanacak eylem planı çalışanlar ve } \\
\text { paydaşlarla ne derece doğru bir şekilde paylaşıldı? }\end{array}$} & ,933 \\
\hline \multicolumn{3}{|c|}{ Yaşanan krizin boyutları ve olası etkilerinin tespiti için ne ölçüde çalışmalar yapıldı? } & ,920 \\
\hline Kaiser-Meyer-Olkin: 0,756 & $\%$ var: 86,985 & Chi Kare: 352,613 & Sig: 0,000 \\
\hline
\end{tabular}

Elde edilen boyutların Cronbach Alfa güvenilirlik katsayısı 0,924 olup Tablo 8'de verilmiş kriterler ışı̆̆ında Mükemmel olarak yorumlanabilir.

Ölçeğin açıkladığı varyans ise yaklaşık \%87>\%50 olmaktadır ki bu da bir birimlik değişimin yaklaşık \%87'nin bu ifadelerle tespit edilebileceği anlamına gelmektedir.

\subsubsection{Faaliyetler ve Tedbirler Ölçeği}

Faaliyetler ve tedbirler ölçeğinde, kriz süresince yönetimin hangi faaliyetlere ağırlık verdiğini ölçümlenmeye çalışılmıştır. Hazırlanan ifadelerde Üretim, Pazarlama ve Finansal Yapılandırma faaliyetlerinin yanı sıra örgütün insan kaynakları dâhil tüm kaynak kullanımlarında, ödenen ücret ve ek faydalarda kesintilere gitmesi ve hem üretim hem yönetim hem de diğer tüm süreç ve faaliyetlerde maliyetleri azaltma olarak tarif 


\section{Aslan - D. Küçükaltan - D. Uzun 12/3 (2020) 2382-2406}

edebileceğimiz Tasarruf ve olmak üzere 4 boyut elde edilmeye çalışılmıştır. Bu durumun tespiti için 14 soru hazırlanmıştır.

Ölçeğimizin KMO değerinin 0,837, Ki-Kare değerinin 797,948 ve Bartlett küresellik test sonucunun anlamlı $(p=0,000)$ çıkması sebebiyle faktör analizine uygun olduğu sonucuna varılmış ve Keşfedici Faktör Analizi (EFA) yapılmıştır. İlk testten sonra bazı ifadelerin çapraz yük alması, bazılarının da herhangi bir faktör altında toplanmaması nedeniyle çıartılmış, bazıları da birleştirilerek 12 ifadeye düşürülmüştür. İkinci testin sonucunda bir ifade daha elemine edilerek toplamda 10 ifadeli ölçek elde edilmiştir.

Ölçekte toplam 3 boyut mevcut olup Eigen değerleri birinci boyutun 4,440, ikinci boyutun 2,032 ve üçüncü boyutun 1,024'tür. Bir sonraki Eigen değeri de 0,525 olarak elde edilmiştir. İkinci testin sonucunda elde edilen sonuçlar ise şöyledir: Ölçeğin determinant değeri 0,005>0,00001 olup ifadeler arasındaki korelasyon matrisinde tüm korelasyonlar 0,90'dan küçüktür. Ters imaj korelasyon tablosunda tüm ölçüm uygunluk değerleri (MSA) 0,50'dan büyük olup tespit edilen en küçük değer 0,648'dir.

Tüm bu veriler ışı̆̆ında Faaliyetler ve Tedbirler ölçeğinde 3 boyut elde edilmiş olup Tablo 11'de analiz sonuçları Şekil 4'te de Scree Plot grafiği verilmiştir.

Tablo 11. Faaliyetler ve Tedbirler Ölçeğinin Faktör ve Güvenilirlik Analizi Sonuçları

\begin{tabular}{|c|c|c|c|}
\hline \multicolumn{4}{|c|}{ FAALIYYETLER VE TEDBİRLER } \\
\hline \multicolumn{4}{|c|}{ ÜRETIM, SATIŞ VE PAZARLAMA FAALİYETLERİ } \\
\hline$\alpha: 0,904$ & \%var: 41,177 & İfade Sayısı: 5 & Faktör Yükü \\
\hline \multicolumn{3}{|c|}{$\begin{array}{l}\text { Rekabetçi konumun sürdürülebilmesi için AR-GE ve ÜR-GE faaliyetlerine ne ölçüde } \\
\text { ağırlık verildi? }\end{array}$} & 872 \\
\hline \multicolumn{3}{|c|}{ Ne ölçüde (ihracat dâhil) daha istikrarlı yeni pazarların arayışına gidildi? } & ,869 \\
\hline \multicolumn{3}{|c|}{ Yeni mal/hizmet arzına yönelik pazarlama faaliyetlerine ne ölçüde ağırlık verildi? } & ,863 \\
\hline \multicolumn{3}{|c|}{$\begin{array}{l}\text { Üretim/hizmet ve operasyon maliyetlerini azaltmak ve verimliliği arttırmak için } \\
\text { ekipmanlara-teknolojiye ne ölçüde yatırımlar yapıldı? }\end{array}$} & 857 \\
\hline \multicolumn{3}{|c|}{ Krizin etkilerini azaltmak için çok aktif bir satış ve pazarlama stratejisi ne ölçüde izlendi? } & 827 \\
\hline \multicolumn{4}{|c|}{ TASARRUF TEDBİRLERİ } \\
\hline$\alpha: 0,655$ & \%var: 17,587 & İfade Sayısı: 3 & Faktör Yükü \\
\hline \multicolumn{3}{|c|}{ İşletme bütçesinin her kaleminde ne ölçüde kesinti yapıldı? } & ,841 \\
\hline \multicolumn{3}{|c|}{ Çalışanlar ne ölçüde ücretsiz izne çıkartıldı veya sayısı azaltıldı? } & ,758 \\
\hline \multicolumn{3}{|c|}{$\begin{array}{l}\text { Kritik stok seviyeleri azaltılarak ve sadece günlük mal/hizmet üretiminin gerektirdiği } \\
\text { oranda hammadde/ara mamul bulundurulmasına ne ölçüde özen gösterildi? }\end{array}$} &, 587 \\
\hline \multicolumn{4}{|c|}{ FINANSAL TEDBİRLER } \\
\hline$\alpha: 0,738$ & \%var: 16,208 & İfade Sayısı: 2 & Faktör Yükü \\
\hline \multicolumn{3}{|c|}{ Alacakların, gerekirse bazı indirimler yapılarak erken tahsilatına ne ölçüde ağırlık verildi? } & ,823 \\
\hline \multicolumn{3}{|c|}{$\begin{array}{l}\text { Finans kuruluşları ve tüm alacaklılarla borçların yeniden yapılandırılması konusunda ne } \\
\text { derece pazarlık yapıldı? }\end{array}$} & ,800 \\
\hline Kaiser-Meyer-Olkin: 0,837 & \%var: 74,971 & Chi Kare: 797,948 & Sig: 0,000 \\
\hline
\end{tabular}




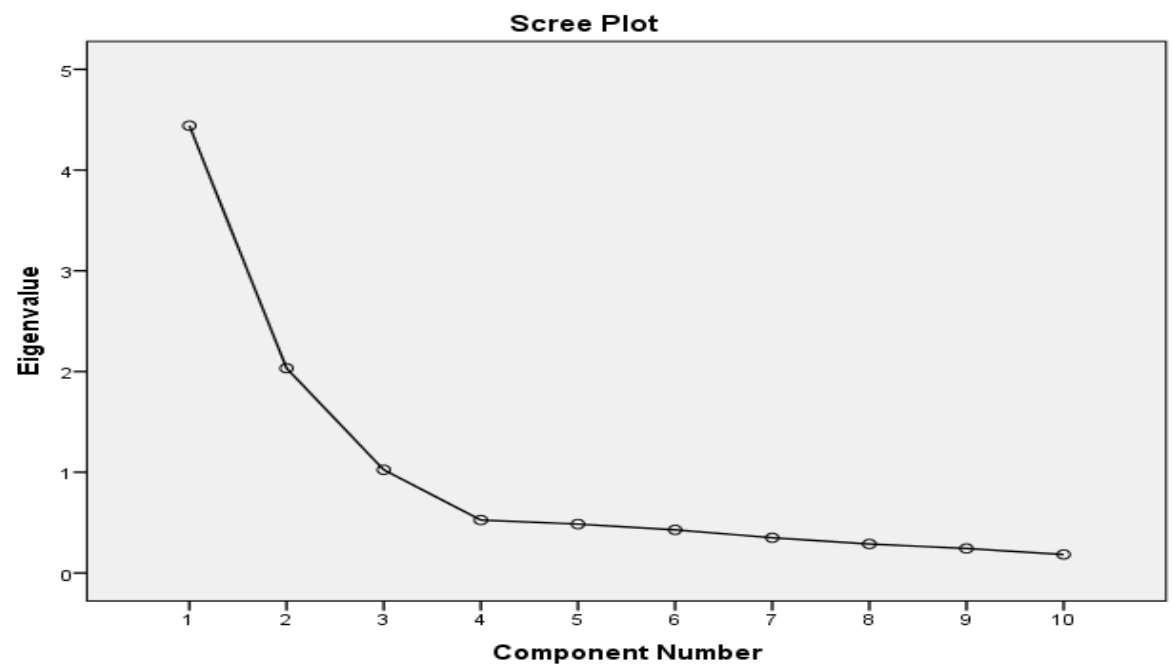

Şekil 4. Faaliyetler ve Tedbirler Ölçeğine Ait Scree Plot Grafiği

Elde edilen boyutların Cronbach Alfa güvenilirlik katsayıları sırasıyla 0,904, 0,655 ve 0,872' dir. En düşük değer olan 0,655 değeri Tasarruf Tedbirleri alt boyutuna ait olup Tablo 8' de verilmiş kriterler 1şığında kabul edilebilir seviyededir. Tüm ölçeğin açıkladığı varyans ise yaklaşık \%75>\%50 olmaktadır.

\subsubsection{Kriz Yönetiminin Algılanan Başarısı Ölçeği}

Bu ölçekte, yönetimin krizi ele alış ve yönetmedeki başarısının ne derece ve nasıl algılandığı tespit edilmeye çalışılmıştır. Çalışanlar tarafından kriz yönetiminin başarılı olduğuna inanıldığı taktirde olumsuz etkilerin kabullenilmesi ve krizden elde edilen tecrübeler 1şığında örgütte gerekli değişikliklerin yapılması mümkün olmaktadır. Aksi takdirde yönetime güven ve inanç zedelenmekte ve tüm olumsuzluklar için yönetim hedef alınmakta, yönetimin uygulamaya koyduğu değişimlerde de dirençle karşılaşılmaktadır.

Bu durumun tespiti için 9 soru hazırlanmıştır. Ölçeğimizin KMO değerinin 0,916, Ki-Kare değerinin 1078,153 ve Bartlett küresellik test sonucunun anlamlı $(\mathrm{p}=0,000)$ çıkması sebebiyle faktör analizine uygun olduğu sonucuna varılmış ve Keşfedici Faktör Analizi (EFA) yapılmıştır. Fakat ilk testten sonra bazı ifadelerin çapraz yük alması, bazılarının da herhangi bir faktör altında toplanmaması nedeniyle çıkartılmış, bazıları da birleştirilerek 7 ifadeye düşürülmüştür. İkinci testin sonucunda bir ifade daha elemine edilerek toplamda 6 ifadeli ölçek elde edilmiştir. Bu boyutun Eigen değeri 5,071'dir (bkz. Şekil 5).

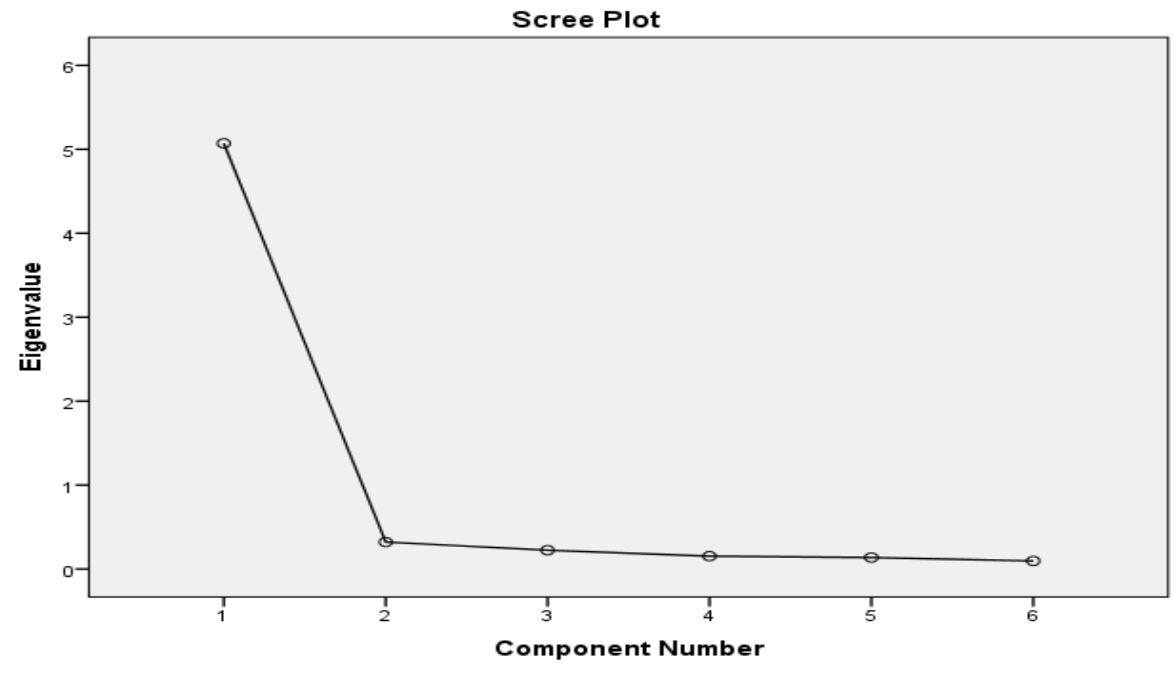

Şekil 5. Kriz Yönetiminin Algılanan Başarısı Ölçeğine Ait Scree Plot Grafiği

İkinci testin sonucunda elde edilen sonuçlar ise şöyledir: Ölçeğin determinant değeri 0,001>0,00001 olup ifadeler arasındaki korelasyon matrisinde tüm korelasyonlar 0,90'dan küçüktür. Ters imaj korelasyon tablosunda tüm ölçüm uygunluk değerleri (MSA) 0,50'dan büyük olup tespit edilen en küçük değer 0,898' dir. 


\section{Aslan - D. Küçükaltan - D. Uzun 12/3 (2020) 2382-2406}

Tüm bu veriler ışı̆̆ında kriz yönetim başarısı ölçeğinde bir boyut elde edilmiş olup Tablo 12'de analiz sonuçları verilmiştir.

Tablo 12. Kriz Yönetiminin Algılanan Başarısı Ölçeğine Ait Faktör ve Güvenilirlik Analizleri

\begin{tabular}{|c|c|c|c|}
\hline \multicolumn{4}{|c|}{ KRİZ YÖNETIMİNIN BAŞARISI } \\
\hline$\alpha: 0,963$ & İfade Sayısı: & & Faktör Yükü \\
\hline \multicolumn{3}{|c|}{ Kriz süresince yönetimin olaylara yaklaşımı ve ele alış şekli } & ,936 \\
\hline \multicolumn{3}{|c|}{ Kriz süresince yönetimin sorunlara farklı çözümler üretmedeki başarısı } & ,936 \\
\hline \multicolumn{3}{|c|}{ Krize zamanında müdahalede yönetimin başarısı } & ,927 \\
\hline \multicolumn{3}{|c|}{$\begin{array}{l}\text { Kriz başında ve süresince yönetimin aldığı kararlar ne derece yerinde ve çözüme } \\
\text { yönelikti? }\end{array}$} & ,926 \\
\hline \multicolumn{3}{|c|}{ Kriz sonrasında yönetimin, normalleşme sürecinde olaylara yaklaşımı ve ele alış şekli } & ,913 \\
\hline \multicolumn{3}{|c|}{ Bu krizi öngörmede yönetimin başarısı } &, 877 \\
\hline Kaiser-Meyer-Olkin: 0,916 & \%var: 84,511 & Chi Kare: 1078,153 & Sig: 0,000 \\
\hline
\end{tabular}

Elde edilen boyutların Cronbach Alfa güvenilirlik katsayısı 0,963 olup Tablo 8'de verilmiş kriterler ışı̆̆ında Mükemmel olarak kabul edilebilir. Tüm ölçeğin açıkladığı varyans ise yaklaşık \%85>\%50 olmaktadır.

\subsubsection{Kriz Yönetiminin Algılanan Başarısına Etki Eden Uygulamalar Ölçeği}

Bu ölçekte, yönetimin krizi ele alış ve yönetmedeki başarılı veya başarısız olarak algılanmasının altında hangi faaliyetlerde yeterince etkili olmadığının, yaptıkları faaliyetlerin nasıl algılandığı tespit edilmeye çalışılmıştır.

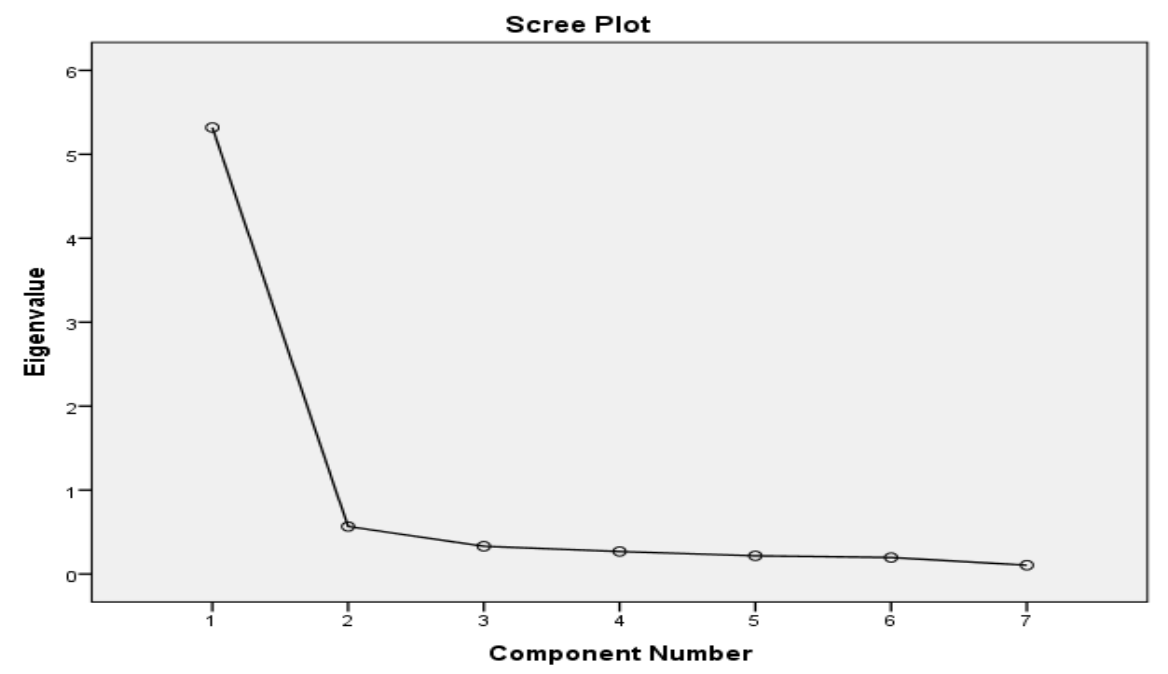

Şekil 6. Kriz Yönetiminin Algılanan Başarısına Etki Eden Uygulamalar Ölçeği Scree Plot Grafiği

Toplam 7 ifadeli ölçeğimizin KMO değerinin 0,907, Ki-Kare değerinin 1003,025 ve Bartlett küresellik test sonucunun anlamlı $(\mathrm{p}=0,000)$ çıkması sebebiyle faktör analizine uygun olduğu sonucuna varılmış ve Keşfedici Faktör Analizi (EFA) yapılmıştır.

Yapılan faktör analizinde tek boyutlu bir ölçek elde edilmiş olup bu boyuta ait Eigen değeri 5,319'dur (bkz. Şekil 6). Analiz sonucunda elde edilen sonuçlar ise şöyledir: Ölçeğin determinant değeri 0,001>0,00001 olup ifadeler arasındaki korelasyon matrisinde tüm korelasyonlar 0,90'dan küçüktür. Ters imaj korelasyon tablosunda tüm ölçüm uygunluk değerleri (MSA) 0,50'dan büyük olup tespit edilen en küçük değer 0,870'tir. Tüm bu veriler ışığında kriz yönetim başarısı ölçeğinde bir boyut elde edilmiş olup Tablo 13'te analiz sonuçları verilmiştir. 
Tablo 13. Kriz Yönetiminin Başarısına Etki Eden Uygulamalar Algısı Ölçeğine Ait Faktör ve Güvenilirlik Analizi Sonuçları

\begin{tabular}{|c|c|c|c|}
\hline \multicolumn{4}{|c|}{ KRIZ YÖNETIMINININ BAŞARISINA ETKİ EDEN UYGULAMALAR } \\
\hline$\alpha: 0,947$ & & V1S1: 7 & Faktör Yükü \\
\hline \multicolumn{3}{|c|}{ Satıs ve pazarlama konusunda alınan önlem ve aksiyonların etkisi } & 924 \\
\hline \multicolumn{3}{|c|}{ Mal/Hizmet, üretim faaliyetlerinde alınan önlem ve aksiyonların etkisi } & ,902 \\
\hline \multicolumn{3}{|c|}{ Sektörel, siyasal ve ekonomik gelişmelerin analiz edilmesi. } & , 898 \\
\hline \multicolumn{3}{|c|}{ Kriz ilk ortaya çıktığında yapılmış olan hazırlık toplantıları ve eylem planlarının etkisi. } & 884 \\
\hline \multicolumn{3}{|c|}{ Finans konusunda alınan önlem ve aksiyonların etkisi. } & ,851 \\
\hline \multicolumn{3}{|c|}{ Çalışanlar ve paydaşlarla iletişimin etkisi. } &, 850 \\
\hline \multicolumn{3}{|c|}{ İnsan Kaynakları konusunda alınan önlem ve aksiyonların etkisi } & ,785 \\
\hline Kaiser-Meyer-Olkin: 0,907 & \%var: 75,982 & Chi Kare: 1003,025 & Sig: 0,000 \\
\hline
\end{tabular}

Elde edilen boyutların Cronbach Alfa güvenilirlik katsayısı 0,97 olup Tablo 8'de verilmiş kriterler ışığında Mükemmel olarak kabul edilebilir. Tüm ölçeğin açıkladığı varyans ise yaklaşık \%76>\%50 olmaktadır.

\subsubsection{Krizin Yansımaları/Etkileri Ölçeği}

Krizin yansımaları ölçeğinde kriz sonrasında yapılan değerlendirme sonucunda örgütün ne derece ve hangi konularda etkilendiğinin, krizin yansımalarınn ne yönde olduğunun tespit edilmesi ve bunların etkisinin büyüklüğ̈̈ ölçümlenmeye çalışılmıştır.

Bu durumun tespiti için 6 soru hazırlanmıştır. Ölçeğimizin KMO değerinin 0,724, Ki-Kare değerinin 213,383 ve Bartlett küresellik test sonucunun anlamlı $(p=0,000)$ çıkması sebebiyle faktör analizine uygun olduğu sonucuna varılmış ve Keşfedici Faktör Analizi (EFA) yapılmıştır. İlk testten sonra bazı ifadelerin çapraz yük alması, bazılarının da herhangi bir faktör altında toplanmaması nedeniyle çıkartılmış, bazıları da birleştirilerek 4 ifadeye düşürülmüştür. İkinci testin sonucunda ise bir ifade daha elenerek toplam 3 ifadeli ölçek elde edilmiştir. Elde edilen boyuta ait Eigen değeri 2,349 olup bu durum Scree Plot grafiğinde de (Şekil 7) görülebilmektedir.

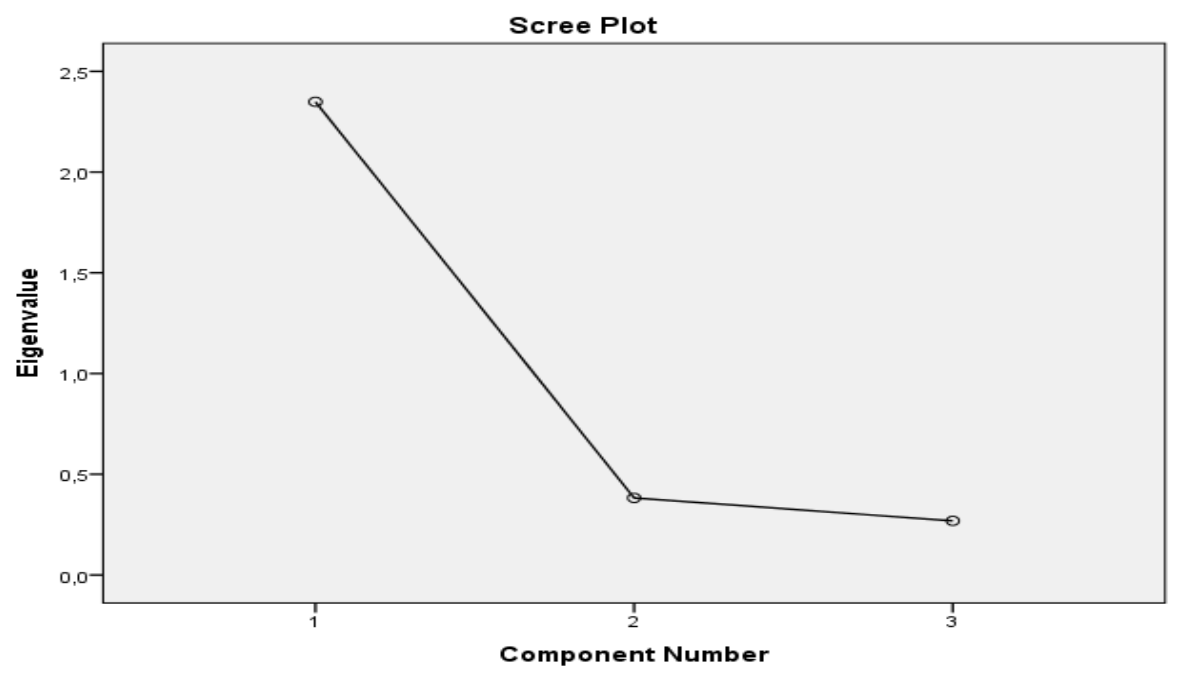

Şekil 7. Krizin Yansımaları Ölçeğine Ait Scree Plot Grafiği

İkinci testin sonucunda elde edilen sonuçlar ise şöyledir: Ölçeğin determinant değeri 0,241>0,00001 olup ifadeler arasındaki korelasyon matrisinde tüm korelasyonlar 0,90'dan küçüktür. Ters imaj korelasyon tablosunda tüm ölçüm uygunluk değerleri (MSA) 0,50'dan büyük olup tespit edilen en küçük değer 0,682' dir. Tüm bu veriler 1şığında Hazırlık ve Planlama ölçeğinde sadece bir tek boyut elde edilmiş olup Tablo 14'te analiz sonuçları verilmiştir. 


\section{Aslan - D. Küçükaltan - D. Uzun 12/3 (2020) 2382-2406}

Tablo 14. Krizin Yansımaları Ölçeğine Ait Faktör ve Güvenilirlik Analizi Sonuçları

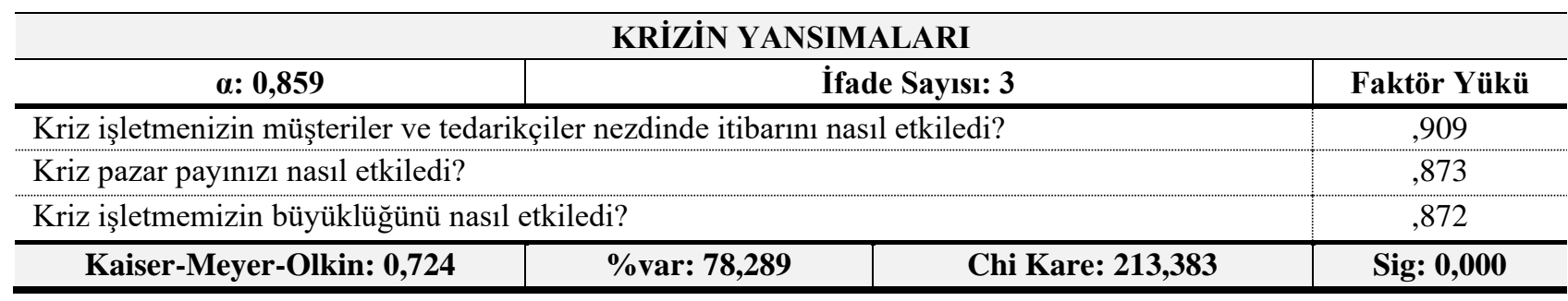

Elde edilen boyutların Cronbach Alfa güvenilirlik katsayısı 0,859 olup Tablo 8'de verilmiş kriterler ışığında “Çok İyi” olarak kabul edilebilir. Tüm ölçeğin açıkladığı varyans ise yaklaşık \%78>\%50 olmaktadır.

\subsubsection{Krizden Öğrenilenlerin Uyarlanması Ölçeği}

Kriz sürecinde elde edilen tecrübeler ve krizin öğrettikleri ile bir sonraki krize hazırlıklı olabilmek adına örgüt yapısında, işleyişinde ve süreçlerinde meydana gelen değişiklikleri tespit etmeye ve bu değişikliklerin derecesi ölçümlenmeye çalışılmıştır. Bu durumun tespiti için 6 soru hazırlanmıştır. Ölçeğimizin KMO değerinin 0,884, Ki-Kare değerinin 724,325 ve Bartlett küresellik test sonucunun anlamlı $(p=0,000)$ çıkması sebebiyle faktör analizine uygun olduğu sonucuna varılmış ve Keşfedici Faktör Analizi (EFA) yapılmıştır. İlk testte tüm ifadeler bir faktör altında toplandığı ve faktör yükleri de kriteri sağladığı için herhangi bir ifade silinmemiştir. İkinci testin sonucunda ise bir ifade elenerek toplam 5 ifadeli ve Eigen değeri 4,123 olan tek boyutlu ölçek elde edilmiştir. Bu ölçeğe ait Scree Plot grafiği Şekil 8'da verilmektedir.

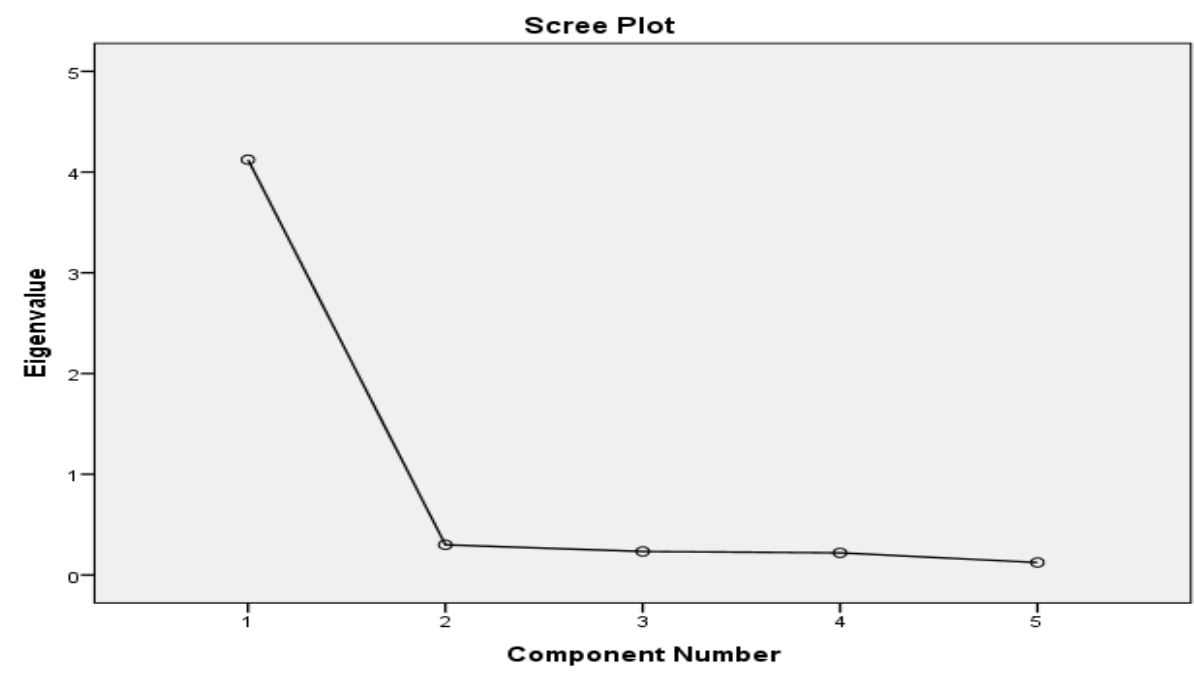

Şekil 8. Krizden Öğrenilenlerin Uyarlanması Ölçeğine Ait Scree Plot Grafiği

İkinci testin sonucunda elde edilen sonuçlar ise şöyledir: Ölçeğin determinant değeri 0,008>0,00001 olup ifadeler arasındaki korelasyon matrisinde tüm korelasyonlar $0,90^{\prime}$ dan küçüktür. Ters imaj korelasyon tablosunda tüm ölçüm uygunluk değerleri (MSA) 0,50' dan büyük olup tespit edilen en küçük değer 0,861'dir. Tüm bu veriler ışığında Hazırlık ve Planlama ölçeğinde sadece bir tek boyut elde edilmiş olup Tablo 15 'te analiz sonuçları verilmiştir.

Tablo 15. Krizden Öğrenilenlerin Uyarlanması Ölçeğine Ait Faktör ve Güvenilirlik Analizleri

\begin{tabular}{|c|c|c|c|}
\hline \multicolumn{4}{|c|}{ KRIZZDEN ÖĞRENILENLERİN UYARLANMASI } \\
\hline$\alpha: 0,947$ & & 1S1: 5 & Faktör Yükü \\
\hline \multicolumn{3}{|c|}{ İşletmenizin uyguladığ $\breve{l}_{1}$ is modeli } & ,924 \\
\hline \multicolumn{3}{|c|}{ İşletmenizin uyguladığı mal/hizmet üretim süreçleri } & ,915 \\
\hline \multicolumn{3}{|c|}{ İşletmenizin uyguladığı satış ve pazarlama süreçleri ve/veya satış sonrası servis süreçleri } & ,914 \\
\hline \multicolumn{3}{|c|}{ İsletmenizin ürettiği mal veya hizmetler } &, 910 \\
\hline \multicolumn{3}{|c|}{ İşletmenizde uygulanan insan kaynakları dâhil tüm idari/yönetsel süreçler } & 876 \\
\hline Kaiser-Meyer-Olkin: 0,884 & \%var: 82,457 & Chi Kare: 724,325 & Sig: 0,000 \\
\hline
\end{tabular}




\section{Aslan - D. Küçükaltan - D. Uzun 12/3 (2020) 2382-2406}

Elde edilen boyutların Cronbach Alfa güvenilirlik katsayısı 0,947 olup Tablo 8'de verilmiş kriterler ışığında Mükemmel olarak kabul edilebilir. Tüm ölçeğin açıkladığı varyans ise yaklaşık \%82>\%50 olmaktadır.

\section{4. Ölçekler}

Faktör analizleri sonucunda elde edilen ölçeklere ait ifade sayıları, boyutları ve güvenilirlik katsayıları Tablo 16 'da topluca verilmektedir.

Tablo 16. Tüm Ölçeklerin Alt Boyutları, İfade Sayıları ve Güvenilirlikleri

\begin{tabular}{|c|c|c|}
\hline ÖLÇEK & $\begin{array}{c}\text { İfade } \\
\text { Sayıları }\end{array}$ & $\begin{array}{c}\text { Cronbach } \\
\alpha\end{array}$ \\
\hline ÇEVRESEL TARAMA & 8 & 0,941 \\
\hline HAZIRLIK VE PLANLAMA & 3 & 0,924 \\
\hline FAALİYETLER VE TEDBİRLER & 10 & 0,834 \\
\hline - Üretim, Satış ve Pazarlama & 5 & 0,904 \\
\hline - Tasarruf Tedbirleri & 3 & 0,655 \\
\hline - Finansal Tedbirler & 2 & 0,738 \\
\hline KRIZZINN YANSIMALARI & 3 & 0,859 \\
\hline KRİZ YÖNETIMMİNİN ALGILANAN BAŞARISI & 6 & 0,963 \\
\hline KRIZ YÖNETIMININN BAŞARISINA ETKİ EDEN UYGULAMALAR & 7 & 0,947 \\
\hline KRİZDEN ÖĞRENİLENLERİN UYARLANMASI & 5 & 0,947 \\
\hline TOPLAM İFADE SAYISI & 42 & \\
\hline
\end{tabular}

Geliştirilmiş ölçekler kullanılarak oluşturulan Yapısal Eşitlik Modeli SmartPLS 3.2.9 versiyonunda (Şekil 9) mevcut veriler ile analiz edilmiştir. Elde edilen sonuçlar geliştirdiğimiz ölçeklerin sadece güvenilirliklerinin değil, aynı zamanda kriz yönetim sürecindeki değişkenleri açıklama düzeylerinin de oldukça iyi bir seviyede olduğunu göstermektedir.

Tablo 17. Değişkenlere Ait R² Değerleri

\begin{tabular}{|l|c|c|}
\hline \multicolumn{1}{|c|}{ Değissken } & $\mathbf{R}^{2}$ & Düzenlenmiş $\mathbf{R}^{2}$ \\
\hline Finansal Tedbirler & 0.087 & 0.084 \\
\hline Hazırlık ve Planlama & 0.606 & 0.605 \\
\hline Krizden Öğrenilenler & 0.709 & 0.705 \\
\hline Krizin Yansımaları & 0.484 & 0.477 \\
\hline Tasarruf Tedbirleri & 0.131 & 0.128 \\
\hline Uygulamaların Algılanan Başarısı & 0.703 & 0.700 \\
\hline Yönetimin Algılanan Başarısı & 0.790 & 0.786 \\
\hline Üretim ve Pazarlama & 0.640 & 0.639 \\
\hline
\end{tabular}




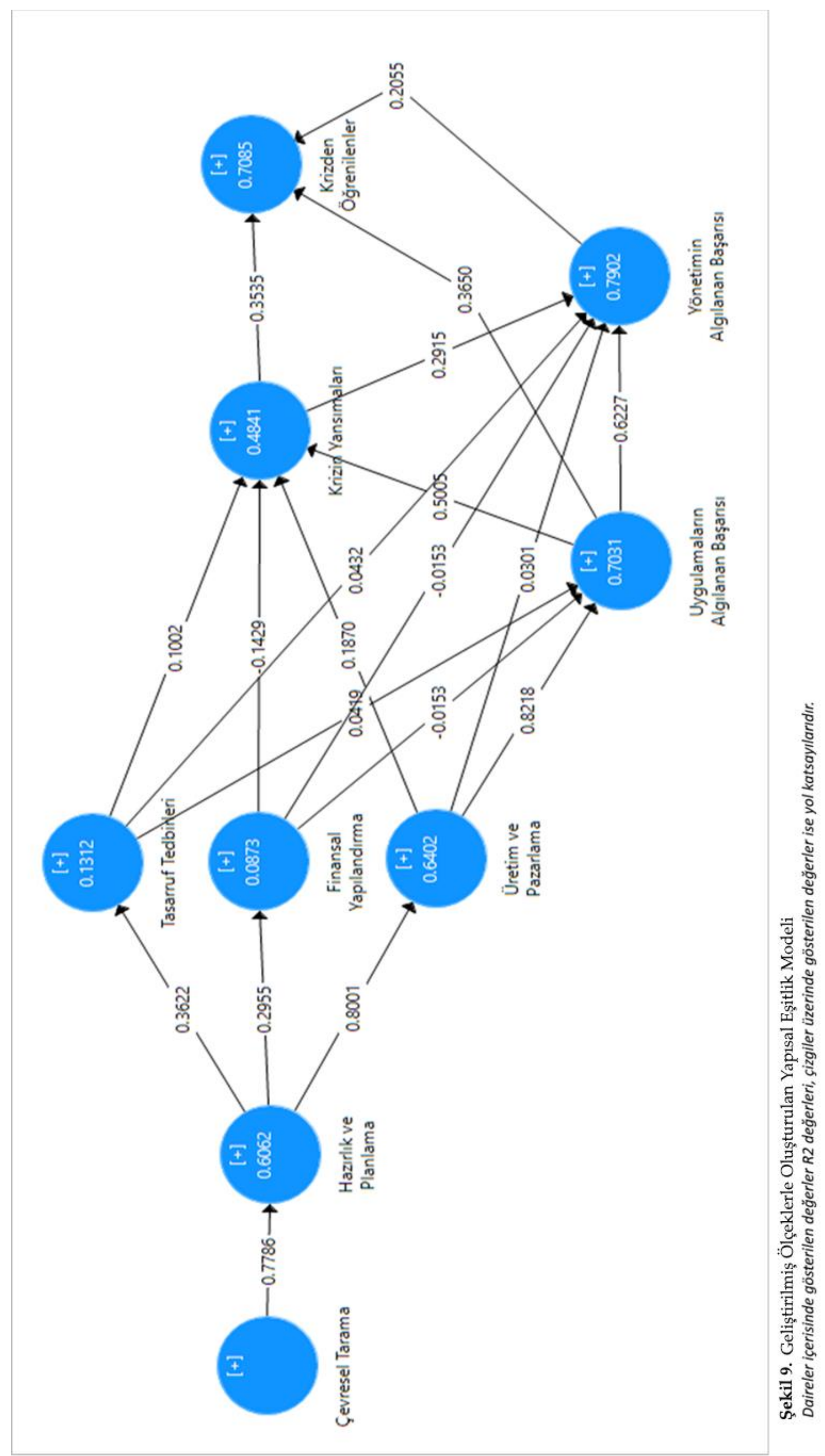




\section{SONUÇ ve TARTIŞMA}

Her ne kadar Çince kriz anlamında kullanılan Weiji kelimesinin "tehlike ve firsat" anlamına geldiği iddiası gerçeği yansıtmasa da kelimenin doğru anlamı olan "dönüm noktası" (Mair, 2009) aslında kriz ve sonrasında yaşanılan süreci tüm yalınlığı ile anlatmaktadır. İyi yönetilemediği zaman neden olduğu hasar veya iyi yönetildiği zaman sunduğu fırsatlarla kriz hem örgütler hem de tüm canlılar için kelimenin tam anlamıla bir dönüm noktası olmaktadır.

Örgütler açısından bu derece hayati öneme sahip ve yıkıcı etkileri olan krizlere hazırlık ve kriz yönetim planları örgütler tarafından ihmal edilmekte (Penrose, 2000:155) ve ancak kriz ortaya çıktığı zaman hazırlıklı olmanın ne derece önemli olduğu kavranmaktadır. Her ne kadar örgütlerin krizleri yönetme süreçleri yönetim stiline, örgüt kültürüne, iletişimin yoğunluğuna ve en önemlisi de krizin nedenlerine dayansa da ister devlet olsun ister işletme ya da STK, tüm örgütler üzerindeki etkileri benzer şekilde ve çoğunlukla da yıkıcı olmaktadir.

Araştırmalarımız sonucunda, yazında bulamadığımızdan dolayı geliştirme ihtiyacı duyduğumuz bu kriz öncesi, süreci ve sonrasında yapılan faaliyetleri ve bu faaliyetlerin hem kriz yönetimine hem de örgüte olan etkilerini değerlendirme ölçeklerdeki ifadeler, literatür taraması, akademisyenler ve çeşitli sektörlerdeki yöneticilerle görüşülerek oluşturulmuştur. Oluşturulan ifade havuzu hem yönetici hem de akademisyen olan kişilerin yardımıyla düzenlenmiştir. Yapılan pilot çalışmada elde edilen verilerle gerçekleştirilen analizler sonrasında ifadelere son hali verilerek saha çalışmasına başlanmıştır. Saha çalışmasında toplanan anketlerden sadece çeşitli pozisyonlarında görev yapan 153 yöneticinin doldurduğu anketler analize dâhil edilmiştir.

Saha çalışmasında elde edilen verilerle öncelikle Keşfedici Faktör Analizi (Exploratory Factor Analysis - EFA) çalışmaları gerçekleştirilmiştir. Daha sonra elde edilen faktörlerin iç tutarlılıklarının belirlenmesi amacıyla güvenilirlik analizleri yapılmıştır. Araştırma kapsamında kullanılan tüm istatistiksel analizlerde anlamlılık düzeyi 0,05 olarak kabul edilmiş ve elde edilen tüm sonuçlar çift yönlü olarak sınanmıştır.

Yapılan çalışma sonucunda örgütlerin kriz öncesi yaptıkları çevresel tarama ve hazırlık, kriz süresince aldıkları finansal tedbirler, tasarruf tedbirleri ve yaptıkları üretim, satış ve pazarlama faaliyetlerini, örgüte yansıyan krizin etkisi ve yaşanılan krizden öğrenilenlerin örgüte uyarlanmasının yanı sıra kriz sürecinde yapılan uygulamaların algılanana başarısı ile kriz yönetiminin algılanan başarısını ölçümleyen 7 ayrı ölçek geliştirilmiştir. Geliştirilmiş ölçekler kullanılarak Yapısal Eşitlik Modeli oluşturulmuş ve mevcut veriler ile analiz edilmiştir. Elde edilen sonuçlar geliştirilen ölçeklerin kriz yönetim sürecindeki değişkenleri açılama düzeylerinin oldukça iyi bir seviyede olduğunu göstermektedir.

Bu çalışmada geliştirilmiş olan kriz yönetim süreci faaliyetlerini ölçümleyen 7 ölçek tek başlarına değil, örgüt kültürü, iletişim, liderlik tarzı veya karar alma tarzı gibi diğer değişkenlerle birlikte kullanıldığı takdirde daha anlamlı sonuçlar üretebilecektir.

Geliştirdiğimiz ölçekler tek başlarına dâhi Krizden Öğrenilenlerin Uyarlanması değişkeninin yaklaşık \% 71'ini, Kriz Yönetiminin Algılanan Başarısının \%79'undan fazlasını, Hazırlık ve Planlamanın \%60'ından fazlasını, Üretim ve Pazarlama Faaliyetlerinin \%64'ünü, Krizin Yansımalarının yaklaşık \%50'sini ve Kriz Yönetimin Başarısına Etki Eden Uygulamalar Algısının yaklaşık \%71'ini ölçüyorsa, diğer değişkenlerle birlikte oluşturulacak modelde bu değerlerin daha da yukarılara gelmesi beklenmelidir.

Geliştirilmiş kriz yönetim ölçeğinin son hali EK-1'de verilmektedir. Veriler 2020 yılı öncesinde toplandığından dolayı etik kurul izni alınmamıştır. 


\section{Aslan - D. Küçükaltan - D. Uzun 12/3 (2020) 2382-2406 \\ Kaynakça}

Abu Amuna, Y. M., Al Shobaki, M. J., Abu Naser, S. S. (2017). Strategic Environmental Scanning: an Approach for Crises Management. International Journal of Information Technology and Electrical Engineering, 6(3), 28-34

Adnan, H. (2015). Effect of Organizational Culture, Organizational Commitment to Performance: Study in Hospital Of District South Konawe of Southeast Sulawesi. The International Journal of Engineering and Science, 4 (5), 33-41

Akdemir, A., Konakay, G. (2016). Dış ve İç Çevre Analizi. Akdemir, A. (Ed.) Örgütlerde Stratejik Yönetim, Orion Kitabevi, Ankara

Akdağ, M. (2001). Halkla İlişkiler ve Kriz Yönetimi. Yayınlanmamış Yüksek Lisans Tezi, Selçuk Üniversitesi Sosyal Bilimler Enstitüsü, Konya

Albright, K. S. (2004). Environmenral Scanning: Radar For Success. The Information Management Journal, Mayıs/Haziran, 38-44

Altaş, M. (2020). Hükümet 100 milyar liralık 'Ekonomik İstikrar Kalkanı' paketini açıkladı. Eişim adresi: https://www.aa.com.tr/tr/ekonomi/hukumet-100-milyar-liralik-ekonomik-istikrar-kalkani-paketiniacikladi/1770907. Erişim Tarihi: 28.03.2020

Arslan, A. (2009). Kriz Yönetiminde Liderlik. Akademik Bakış, 18, 179-190

Bezemer, D. (2009). Why some economists could see the crisis coming, Financial Times. Erişim Adresi: https://www.ft.com/content/452dc484-9bdc-11de-b214-00144feabdc0., Erişim Tarihi: 26.03.2020

Büyükakın, F., Aydın, S. (2018). Öncü Göstergelerle Finansal Kırılganlık Endeksi: Türkiye Örneği (1990-2017). Kocaeli Üniversitesi Sosyal Bilimler Dergisi, 36, 113-125

Cabrera-Nguyen, P. (2010). Author Guidelines for Reporting Scale Development and Validation Results in the Journal of the Society for Social Work and Research. Journal of the Society for Social Work and Research. 1(2), 99-103

Carpenter S. (2018). Ten Steps in Scale Development and Reporting: A Guide for Researchers. Communication Methods and Measures, 12(1), 25-44

Christophersen, O. A., Haug, A. (2007). More about hypervirulent avian influenza: Is the world now better prepared? Microbial Ecology in Health and Disease, 19(2), 78-121

Çiftçi, G. (2015). Turizm İşletmelerinde Kriz Yönetimi Uygulamalarının Örgütsel Öğrenme ve İşletme Performansı Açısından Ampirik Olarak Analizi. Yayınlanmamış Doktora Tezi, Namık Kemal Üniversitesi, Sosyal Bilimler Enstitüsü, İşletme Anabilim Dalı, Tekirdağ

Dinçer, Ö. (2000). Stratejik Yönetim ve İşletme Politikası (5. Baskı). İstanbul: Beta Basım Yayım Dağıtım

Ferik, M. (2015). Recep Tayyip Erdoğan'lı Yillar. İstanbul: E-Kitap Projesi

Field, A. (2018). Discovering statistics using IBM SPSS statistics (5. Bask1). Londra: SAGE Publications

Fields, D. (2002). Taking Measure of Work: A Guide to Validated Scales for Organizational Research and Diagnosis. Thousand Oaks, CA: SAGE Publications

Hair, J. F. J., Black, W. C., Babin, B. J., \& Anderson, R. E. (2010). Multivariate Data Analysis (17. Bask1). NJ: Prentice Hall

Henig, R. M. (2020). Why weren't we ready for this virus? National Geographic, Temmuz-2020, Erişim Adresi: https://www.nationalgeographic.com/magazine/2020/07/why-werent-we-ready-for-this-virus/, Erişim Tarihi: 28.06 .2020

Herlant, M. (2020). How your organization can assess and respond to COVID-19 related risks. Ernest \& Young, Erişim Adresi: https://www.ey.com/en_be/covid-19/is-your-organization-prepared-to-respond 


\section{Aslan - D. Küçükaltan - D. Uzun 12/3 (2020) 2382-2406}

Israeli, A. A., Reichel, A. (2003). Hospitality crisis management practices: the Israeli case. Hospitality Management, 22, 353-372

İncaz, S. (2018). Kriz Açısından Yönetim. Akdemir, A. (Ed.) Örgütlerin Yönetimi: Kavramsal-Kuramsal, Tematik ve Kurumsal Açılardan Yönetim, Beta Yayınları, İstanbul, 455-474

Jaques, T. (2008). A case study approach to issue and crisis management: Schadenfreude or an opportunity to $\begin{array}{llll}\text { learn?. Journal of Communication } & \text { Management, 12(3), }\end{array}$ https://doi.org/10.1108/13632540810899399

Karakurt, B. (2010). Küresel Mali Krizi Önlemede Maliyet Politikasının Rolü ve Türkiye'nin Krize Maliye Politikası Cevab1. Atatürk Üniversitesi İktisadi ve İdari Bilimler Dergisi, 24(2), 167-195

Kılıç, S. (2016). Cronbach'ın Alfa Güvenilirlik Katsayısı. Journal of Mood Disorders, 6(1), 47-48

King, G. (2002). Crisis Management \& Team Effectiveness: A Closer Examination. Journal of Business Ethics, 41, $235-249$

Kline, R. (2005). Principles and practice of structural equation modeling (2nd ed.). New York, NY: Guilford Press

Köroğlu, A. (2004). Turizmde kriz yönetimi: otel işletmelerinde ve seyahat acentalarında bir uygulama. Yayımlanmamış doktora tezi, Balıkesir Üniversitesi Sosyal Bilimler Enstitüsü, Balıkesir

Kutlu, H. A., Demirci, N. S. (2011). Küresel Finansal Krizi (2007-?) Ortaya Çıkaran Nedenler, Krizin Etkileri, Krizden Kısmi Çıkıs Ve Mevcut Durum. Muhasebe ve Finans Dergisi, Ekim-2011, 121-136

Küçükaltan, D., Badem, M., Albayrak, M. (2006). Küresel Ekolojik ve Biyolojik Krizler Ekseninde Türkiye'de Kırsal Turizm, Türkiye VII. Tarım Ekonomisi Kongresinde Sunulan Bildiri, Antalya

Lyberg, L., Biemer, P., Collins, M., De Leeuw, E., Dippo, C., Schwarz, N., \& Trewin, D. (1997). Survey measurement and process quality. New York: Wiley

Mair, V. H. (2009). How a misunderstanding about Chinese characters has led many astray. Erişim Adresi: http://pinyin.info/chinese/crisis.html, Erişim Tarihi: 29.06.2020

Mert, G., Alan, T. (2020). Girişimcilerin Kriz Algısı ve Kriz İle Başa Çıkma Stratejileri. Social, Mentality and Researcher Thinkers Journal, 6(32), 1048-1064

Mitroff vd., I., Shrivastava, P., Udwadia, F. (1987). Effective Crisis Management. Academy of Management Executive, 1(3), 283-292

Monella, L. M. (2020). COVID-19 outbreak in Italy: What are other EU countries doing? Erişim Adresi: https://www.euronews.com/2020/02/24/covid-19-outbreak-in-italy-what-are-other-eu-countriesdoing . Erişim Tarihi: 27.02.2020

Sağlık Bakanlığı (2020). Türkiye'deki Günlük COVID-19 Vaka Sayıları. Erişim Adresi: https://covid19bilgi.saglik.gov.tr/tr/haberler/turkiye-deki-gunluk-covid-19-vaka-sayilari.html, Erişim Tarihi: 28.06 .2020

Okumuş, F. (2003). İşletmelerde kriz yönetimi ve krizlerin işletmeler üzerine olası etkileri. İktisadi ve İdari Bilimler Dergisi, 17(1-2), 203-212

Özdemir, L. (2014) 2008 Küresel Ekonomik Krizinin Örgütsel Etkileri ve Bir Ölçek Geliştirme. Yönetim Bilimleri Dergisi, 12(23), 79-105

Özdevecioğlu, M. (2002). Krizin İşletmelerin Yönetsel ve Örgütsel Yapısı Üzerindeki Olumsuz Etkileri Ve Kayseri Sanayi İşletmelerinde Yapılan Bir Araştırma. Erciyes Üniversitesi İktisadi ve İdari Bilimler Fakültesi Dergisi, 19, 93-114

ParaAnaliz (2019). Krizin en Net Göstergesi: Kapanan Şirket Sayısı Patlama Yapmış! Erişim Adresi: https://www.paraanaliz.com/2019/turkiye-ekonomisi/krizin-en-net-gostergesi-kapanan-sirket-sayisipatlama-yapmis-34019, Erişim Tarihi: 28.06.2020

Penrose, J. M. (2000). The Role of Perception in Crisis Planning. Public Relations Review, 26(2), 155-171 


\section{Aslan - D. Küçükaltan - D. Uzun 12/3 (2020) 2382-2406}

PwC (2019). PwC Küresel Kriz Araştırması 2019. Erişim Adresi: https://www.pwc.com.tr/kuresel-krizarastirmasi-2019. Erişim Tarihi: 19.03.2020

PwC (2020). COVIC-19 Özelinde İşveren Bilgilendirme Rehberi. PwC Türkiye Sosyal Güvenlik Bülteni, Sayı: 15

Radu, S. (2020). The Billions That Countries Are Spending to Fight COVID-19. Erişim Adresi: https://www.usnews.com/news/best-countries/articles/2020-03-19/increasing-number-of-countriespush-coronavirus-rescue-packages. Erişim Tarihi: 28.03.2020

Reilly, A. H. (1993). The Technology of Effective Crisis Management: More Than Daily Routine. The Journal of High Technology Management Research, 4(1), 27-46

Richardson, B. (1994). Crisis Management and Management Strategy-Time to "Loop the Loop"? Disaster Prevention and Management, 3(3), 59-80. https://doi.org/10.1108/09653569410795632

Russo, T. A., Katzel, A. J. (2011). The 2008 Financial Crisis and Its Aftermath: Addressing the Next Debt Challenge (Occasional Paper No. 82). Group of Thirty, Washington DC

Sarstedt M., Mooi E. (2014). Factor Analysis. In: A Concise Guide to Market Research (Springer Texts in Business and Economics). Berlin: Springer

Sheaffer, Z., Mano-Negrin, R. (2003). Executives' Orientations as Indicators of Crisis Management Policies and Practices. Journal of Management Studies, 40(2), 573-606

Shi, J., Cui, Y. (2011). Exploring the Structure of the Crisis Management Team. Key Engineering Materials Vols $460-461,15-20$

Starosta, A. (2014). Anti-crisis Management Strategies. The case of companies in the Greater Poland Voivodeship. Management, 18(1), 255-266

Şen, A. (2005). Finansal Krizlerin Tahmin Edilebilirliği: Türkiye Uygulaması, Yayınlanmamış Doktora Tezi, İstanbul Üniversitesi Sosyal Bilimler Enstitüsü: İstanbul

Tabachnick, B. G., Fidell, L. S. (2019). Using Multivariate Statistics (7. Baskı). NY: Pearson

TOBB (2020). İş Dünyası Corona Virüs İçin Ekonomik Tedbirler. Erişim Adresi: https://tobb.org.tr/Sayfalar/20200323-covid-destegi.php, Erişim Tarihi: 28.03.2020

TOBB (2018). 2018 Aralık Ayına Ait Kurulan ve Kapanan Şirket İstatistikleri Haber Bülteni. Erişim Adresi: https://www.tobb.org.tr/BilgiErisimMudurlugu/Documents/ResmiDosya/2018/2018-12.doc, Erişim Tarihi: 28.06 .2020

Trochim, W. M. K. (2020). Likert Scaling. Research Methods Knowledge Base. Erişim Adresi: https://conjointly.com/kb/likert-scaling/, Erişim Tarihi: 29.06.2020

Ülgen, H., Mirze, K. (2018). İşletmelerde Stratejik Yönetim (9. Baskı). İstanbul: Beta Yayınlar

Ürü Sanı, F. O. (2018). Stratejik Açıdan Yönetim. Akdemir, A. (Ed.) Örgütlerin Yönetimi. Beta Yayınları, İstanbul, 401-454

WHO (2020). The First Few X cases and contacts (FFX) investigation protocol for coronavirus disease 2019 (COVID19) (Referens Number: WHO/2019-nCoV/FFXprotocol/2020.2)

Worthington, R., \& Whittaker, T. (2006). Scale development research: A content analysis and recommendations for best practices. Counseling Psychologist, 34, 806-838

Yıldırım, S. (2010). 2008 Yılı Küresel Ekonomi Krizinin Dünya ve Türkiye Ekonomisine Etkileri. KMÜ Sosyal ve Ekonomik Araştırmalar Dergisi,12(18), 47-55

Yiğit, S., Yiğit, A. M. (2011). Stratejik Yönetimde Dış Çevre Analizi: KOBİ'ler ve Büyük İşletmeler Arasında Bir Karşılaştırma. Erciyes Üniversitesi İktisadi ve İdari Bilimler Fakültesi Dergisi, 38, 119-136 


\begin{tabular}{|c|c|c|c|c|c|c|c|c|}
\hline \multicolumn{2}{|c|}{$\begin{array}{l}\text { Lütfen aşağıdaki soruları, yukarıda belirtmiş olduğunuz krizi göz } \\
\text { önünde bulundurarak cevaplayınız. }\end{array}$} & :un & $\begin{array}{l}\frac{N}{4} \\
\frac{y}{0}\end{array}$ & $\frac{N}{4}$ & $\underset{\Xi}{\mathbb{E}}$ & 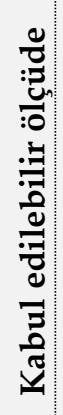 & 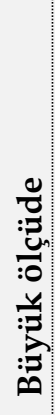 & 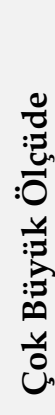 \\
\hline \multirow{8}{*}{ 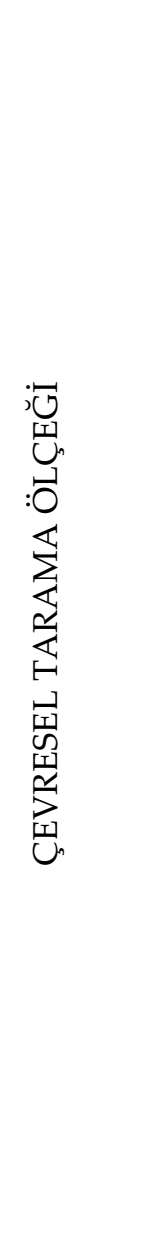 } & $\begin{array}{l}\text { İşletmeniz dâhilinde krize neden olabilecek potansiyel tehlike } \\
\text { ve risklere (kaza, yangın, çatışma, grev, geri dönüşü yüksek } \\
\text { maliyetli yanlış veya hatalı üretim/tasarım vb.) karşı ne ölçüde } \\
\text { önlemler alınırdı? }\end{array}$ & 1 & 2 & 3 & 4 & 5 & 6 & 7 \\
\hline & $\begin{array}{l}\text { Rakip ve olası rakiplerin faaliyetleri ne ölçüde takip ve analiz } \\
\text { edilirdi? }\end{array}$ & 1 & 2 & 3 & 4 & 5 & 6 & 7 \\
\hline & $\begin{array}{l}\text { Önceden yaşanan krizlerden elde edilen tecrübeler ışığında, } \\
\text { gerekli önlemler ne ölçüde alınır ve uygulanırdı? }\end{array}$ & 1 & 2 & 3 & 4 & 5 & 6 & 7 \\
\hline & $\begin{array}{l}\text { Faaliyet gösterilen pazarda sektörel, siyasi, ekonomik } \\
\text { gelişmeler ne ölçüde takip edilir, pazara olabilecek olası etkileri } \\
\text { analiz edilirdi? }\end{array}$ & 1 & 2 & 3 & 4 & 5 & 6 & 7 \\
\hline & $\begin{array}{l}\text { Faaliyet gösterilen pazarda talep ve tercihlerdeki değişimler ne } \\
\text { ölçüde önceden araştırılıp gerekli aksiyonlar alınırdı? }\end{array}$ & 1 & 2 & 3 & 4 & 5 & 6 & 7 \\
\hline & $\begin{array}{l}\text { Üretim, satış, bakım/onarım, kaynak kullanımı, insan } \\
\text { kaynakları vb. gibi raporlar ne ölçüde hazırlanır, incelenir ve } \\
\text { gerekli aksiyonlar alınırdı? }\end{array}$ & 1 & 2 & 3 & 4 & 5 & 6 & 7 \\
\hline & $\begin{array}{l}\text { Ne ölçüde üretim/hizmet dahil tüm faaliyetlerle ilgili } \\
\text { gelişmeler takip edilir işletmenize uyarlanırdı? }\end{array}$ & 1 & 2 & 3 & 4 & 5 & 6 & 7 \\
\hline & $\begin{array}{l}\text { Ne ölçüde iç iletişime, çalışan ve paydaşlarla bilgi paylaşımına } \\
\text { önem verilirdi? }\end{array}$ & 1 & 2 & 3 & 4 & 5 & 6 & 7 \\
\hline \multirow{3}{*}{ 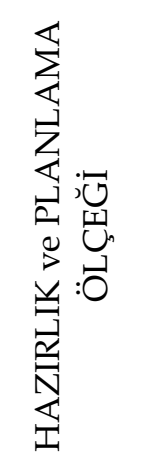 } & $\begin{array}{l}\text { Yaşanan krizin boyutları ve olası etkilerinin tespiti için ne } \\
\text { ölçüde çalışmalar yapıldı? }\end{array}$ & 1 & 2 & 3 & 4 & 5 & 6 & 7 \\
\hline & $\begin{array}{l}\text { Krizden çıkış için yapılması gerekenlerle ilgili takımlar } \\
\text { oluşturuldu mu? ve gerekli çalışmaları yapmaları ne ölçüde } \\
\text { sağlandı? }\end{array}$ & 1 & 2 & 3 & 4 & 5 & 6 & 7 \\
\hline & $\begin{array}{l}\text { Krizin boyutları, etkileri ve krizi aşmak için uygulanacak } \\
\text { eylem planı çalışanlar ve paydaşlarla ne derece doğru bir } \\
\text { şekilde paylaşıldı? }\end{array}$ & 1 & 2 & 3 & 4 & 5 & 6 & 7 \\
\hline 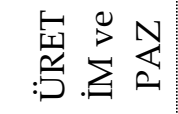 & $\begin{array}{l}\text { Krizin etkilerini azaltmak için çok aktif bir satış ve pazarlama } \\
\text { stratejisi ne ölçüde izlendi? }\end{array}$ & 1 & 2 & 3 & 4 & 5 & 6 & 7 \\
\hline
\end{tabular}




\begin{tabular}{|c|c|c|c|c|c|c|c|c|}
\hline & $\begin{array}{l}\text { Yeni mal/hizmet arzına yönelik pazarlama faaliyetlerine ne } \\
\text { ölçüde ağırlık verildi? }\end{array}$ & 1 & 2 & 3 & 4 & 5 & 6 & 7 \\
\hline & $\begin{array}{l}\text { Ne ölçüde (ihracat dâhil) daha istikrarlı yeni pazarların } \\
\text { arayışına gidildi? }\end{array}$ & 1 & 2 & 3 & 4 & 5 & 6 & 7 \\
\hline & $\begin{array}{l}\text { Üretim/hizmet ve operasyon maliyetlerini azaltmak ve } \\
\text { verimliliği arttırmak için ekipmanlara-teknolojiye ne ölçüde } \\
\text { yatırımlar yapıldı? }\end{array}$ & 1 & 2 & 3 & 4 & 5 & 6 & 7 \\
\hline & $\begin{array}{l}\text { Rekabetçi konumun sürdürülebilmesi için AR-GE ve ÜR-GE } \\
\text { faaliyetlerine ne ölçüde ağırlık verildi? }\end{array}$ & 1 & 2 & 3 & 4 & 5 & 6 & 7 \\
\hline \multirow{3}{*}{ 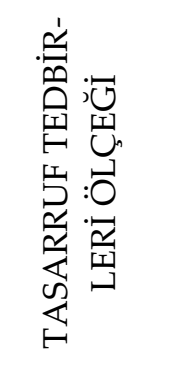 } & $\begin{array}{l}\text { Çalışanlar ne ölçüde ücretsiz izne çıkartıldı veya sayısı } \\
\text { azaltıldı? }\end{array}$ & 1 & 2 & 3 & 4 & 5 & 6 & 7 \\
\hline & İşletme bütçesinin her kaleminde ne ölçüde kesinti yapıldı? & 1 & 2 & 3 & 4 & 5 & 6 & 7 \\
\hline & $\begin{array}{l}\text { Kritik stok seviyeleri azaltılarak ve sadece günlük mal/hizmet } \\
\text { üretiminin gerektirdiği oranda hammadde/ara mamul } \\
\text { bulundurulmasına ne ölçüde özen gösterildi? }\end{array}$ & 1 & 2 & 3 & 4 & 5 & 6 & 7 \\
\hline \multirow{2}{*}{ 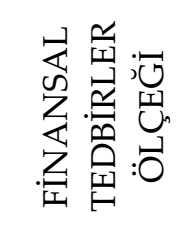 } & $\begin{array}{l}\text { Finans kuruluşları ve tüm alacaklılarla borçların yeniden } \\
\text { yapılandırılması konusunda ne derece pazarlık yapıldı? }\end{array}$ & 1 & 2 & 3 & 4 & 5 & 6 & 7 \\
\hline & $\begin{array}{l}\text { Alacakların, gerekirse bazı indirimler yapılarak erken } \\
\text { tahsilatına ne ölçüde ağırlık verildi? }\end{array}$ & 1 & 2 & 3 & 4 & 5 & 6 & 7 \\
\hline \multicolumn{2}{|c|}{$\begin{array}{l}\text { Yöneticilerinizin krizi öngörmede, kriz süreci ve sonrasındaki yönetim } \\
\text { ve uygulamalarındaki başarısını nasıl değerlendirirsiniz? }\end{array}$} & 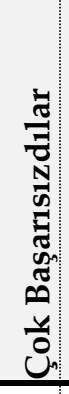 & 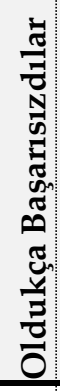 & 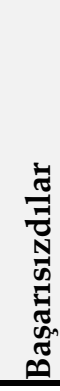 & 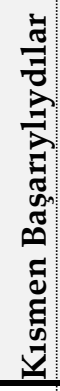 & 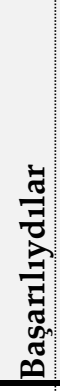 & 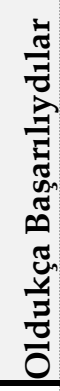 & 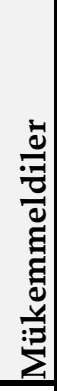 \\
\hline \multirow{5}{*}{ 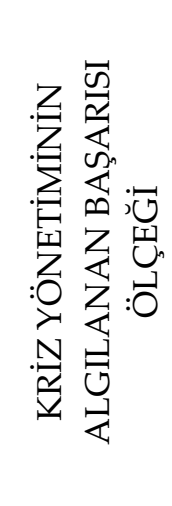 } & Bu krizi öngörmede yönetimin başarısı & 1 & 2 & 3 & 4 & 5 & 6 & 7 \\
\hline & Krize zamanında müdahalede yönetimin başarısı & 1 & 2 & 3 & 4 & 5 & 6 & 7 \\
\hline & Kriz süresince yönetimin olaylara yaklaşımı ve ele alış şekli & 1 & 2 & 3 & 4 & 5 & 6 & 7 \\
\hline & $\begin{array}{l}\text { Kriz süresince yönetimin sorunlara farklı çözümler üretmedeki } \\
\text { başarısı }\end{array}$ & 1 & 2 & 3 & 4 & 5 & 6 & 7 \\
\hline & $\begin{array}{l}\text { Kriz sonrasında yönetimin, normalleşme sürecinde olaylara } \\
\text { yaklaşımı ve ele alış şekli }\end{array}$ & 1 & 2 & 3 & 4 & 5 & 6 & 7 \\
\hline
\end{tabular}




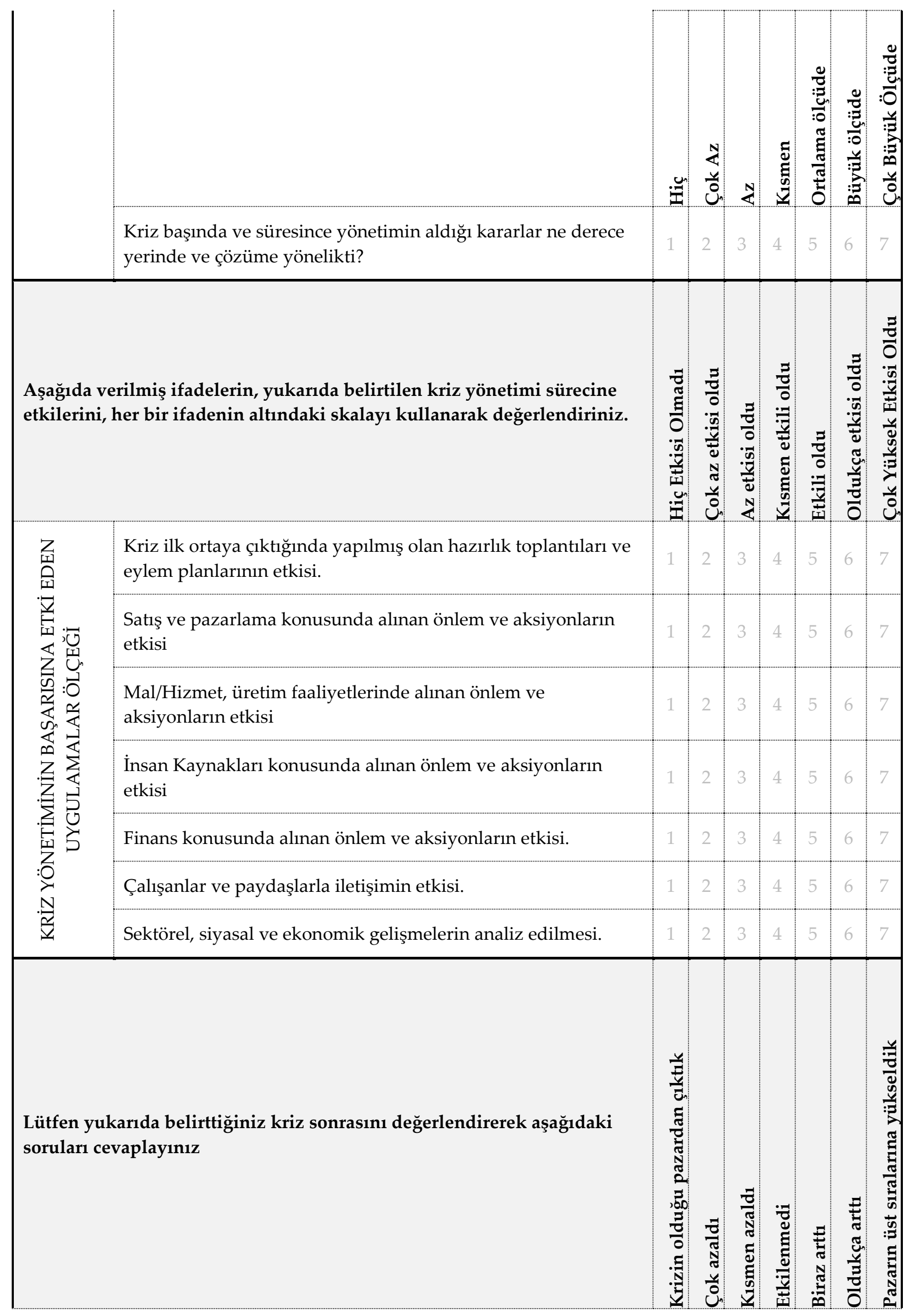




\begin{tabular}{|c|c|c|c|c|c|c|c|c|}
\hline & Kriz pazar payınızı nasıl etkiledi? & 1 & 2 & 3 & 4 & 5 & 6 & 7 \\
\hline 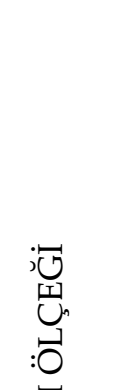 & & 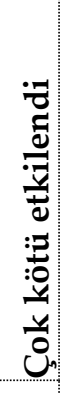 & : & 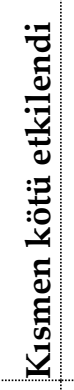 & 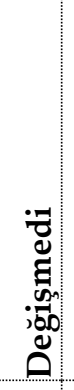 & 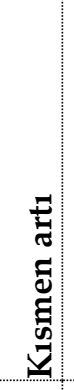 & $\frac{Z}{2}$ & 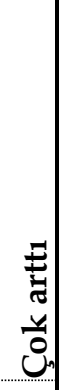 \\
\hline$\underset{\longleftarrow}{\stackrel{2}{4}}$ & $\begin{array}{l}\text { Kriz işletmenizin müşteriler ve tedarikçiler nezdinde itibarını } \\
\text { nasıl etkiledi? }\end{array}$ & 1 & 2 & 3 & 4 & 5 & 6 & 7 \\
\hline 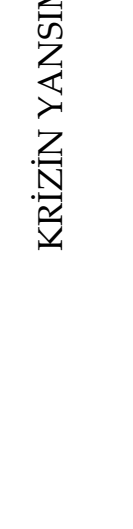 & & 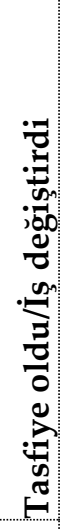 & := & 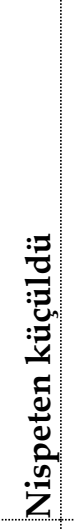 & 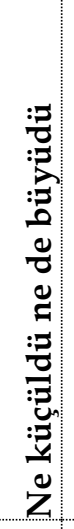 & : & 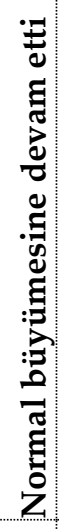 & 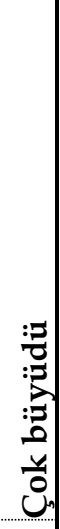 \\
\hline & Kriz işletmemizin büyüklüğünü nasıl etkiledi? & 1 & 2 & 3 & 4 & 5 & 6 & 7 \\
\hline Kriz, aşa & da belirtilen hususlarda ne ölçüde değişikliğe neden oldu? & 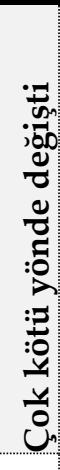 & 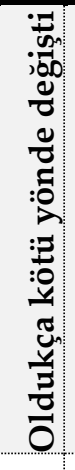 & 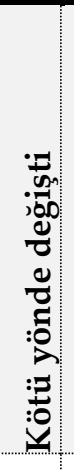 & , & 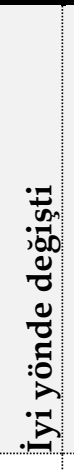 & 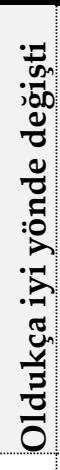 & 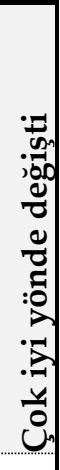 \\
\hline 疍 & $\begin{array}{l}\text { İşletmenizde uygulanan insan kaynakları dâhil tüm } \\
\text { idari/yönetsel süreçler }\end{array}$ & 1 & 2 & 3 & 4 & 5 & 6 & 7 \\
\hline 胥 & İşletmenizin uyguladığı mal/hizmet üretim süreçleri & 1 & 2 & 3 & 4 & 5 & 6 & 7 \\
\hline 武苦 & İşletmenizin ürettiği mal veya hizmetler & 1 & 2 & 3 & 4 & 5 & 6 & 7 \\
\hline 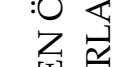 & İşletmenizin uyguladığı iş modeli & 1 & 2 & 3 & 4 & 5 & 6 & 7 \\
\hline 苗 & $\begin{array}{l}\text { İşletmenizin uyguladığı satış ve pazarlama süreçleri ve/veya } \\
\text { satış sonrası servis süreçleri }\end{array}$ & 1 & 2 & 3 & 4 & 5 & 6 & 7 \\
\hline
\end{tabular}

